\title{
Factors controlling the seasonal variation in soil water content and pore water pressures within a lightly vegetated clay slope
}

\author{
J. A. SMEThURST*, D. CLARKE* and W. POWRIE*
}

\begin{abstract}
Seasonal cycles of soil water content cause shrinking and swelling in clay soils, which can in turn contribute to strain-softening and progressive slope failure. This paper presents and analyses six years of field measurements of soil water content and pore water pressures in the upper layers of a lightly vegetated London Clay slope near Newbury, UK, and shows how they can be related quantitatively to the climate using a water balance model. The field observations are set in the context of a 40-year run of rainfall data for the site. Moderately extreme rainfall and drought events were experienced over the period 2003-2008, allowing almost the full variation in likely pore water pressures to be characterised. Pore water pressures were found to return to near hydrostatic during most winters. Variations in summer rainfall, particularly during June-August, are shown to have a large influence on the magnitude of the cycles of pore water pressure and effective stress. The 40 -year rainfall dataset is used to calculate approximate return periods for the observed soil conditions, and provides a benchmark for calculating the impacts of expected climate change on similar sites.
\end{abstract}

KEYWORDS: clays; monitoring; pore pressures; slopes; suction; vegetation
Les cycles de teneur en eau des sols peuvent donner lieu à la rétraction et au gonflement de sols argileux, qui peuvent, à leur tour, contribuer à un radoucissement et à une défaillance progressive des pentes. La présente communication présente et analyse 6 années de mesures sur le terrain de la teneur en eau de sols et de pressions de l'eau interstitielle dans les couches supérieures d'une pente d'argile de Londres, près de Newbury, en Angleterre, en illustrant la façon dont elles peuvent dépendre, sur un plan quantitatif, du climat, en utilisant un modèle de bilan hydrologique. Les observations sur le terrain sont présentées dans le contexte d'une série de relevés de la pluviosité pour le site, effectués sur une période de 40 ans. La période 2003 - 2008 a été marquée par une pluviosité modérément extrême et des cas de sécheresse, ce qui a permis de caractériser un éventail quasiment complet des pressions de l'eau interstitielle. On a relevé que les pressions de l'eau interstitielle retrouvent des niveaux quasiment hydrostatiques pendant la plupart des hivers. De plus, il s'avère que les variations de la pluviosité en été, notamment dans la période allant de juin à août, ont un effet marquant sur la magnitude des cycles de pression de l'eau interstitielle et des tensions efficaces. On utilise les données relatives à la pluviosité sur 40 ans pour calculer des périodes de retour approximatives pour les conditions du sol relevées, et ces données fournissent des valeurs de référence pour le calcul de l'impact de changements climatiques prévus sur des sites similaires.

\section{INTRODUCTION}

In temperate climates, water demand by vegetation peaks in summer, and is out of phase with the season of greatest rainfall in winter. In clays exhibiting volume change, these seasonal cycles of wetting and drying cause the soil to shrink and swell, and result in changes in pore water pressures, and hence effective stress, of up to about $500 \mathrm{kPa}$ close to the ground surface (O'Brien et al., 2004). In cutting and embankment slopes, these cycles of volume and stress change cause or exacerbate various slope instability and serviceability problems: excessive differential vertical displacements, which cause distortion to rail tracks on old vegetated embankments (Andrei, 2000; O’Brien, 2007); progressive, deep-seated slope failure (Kovacevic et al., 2001; Nyambayo et al., 2004; O'Brien et al., 2004); shallow instability caused by rapid rainfall infiltration by way of summer tension cracks into the surface zone of the slope (Anderson \& Kneale, 1980; Parsons \& Perry, 1985); and surface movement, driven by volume changes in the surface wetting and drying zone (Greenwood, 1998; Take \& Bolton, 2004).

Manuscript received 13 September 2010; revised manuscript accepted 16 September 2011.

Discussion on this paper is welcomed by the editor.

* Faculty of Engineering and Environment, University of Southampton, UK
Finite-element/difference models have been used to explore the development of both deep-seated and shallower progressive failures in slopes constructed of strain-softening clays (e.g. Vaughan et al., 2004). These models have typically used bi-modal 'summer' and 'winter' pore water pressure surface conditions to represent the seasonal influence of the climate and vegetation (e.g. Kovacevic et al., 2001; Nyambayo et al., 2004; O'Brien et al., 2004). Analyses have shown that, under given geometric and boundary conditions (including imposed surface pore water pressure), the slope may fail after a number of seasonal cycles. For a given geometry and soil strength, the number of years to failure will depend on the magnitude of seasonal pore water pressure variation in the model, and the magnitude of residual surface suctions at the end of winter (Kovacevic et al., 2001; Nyambayo et al., 2004). The approach in which bi-modal 'summer' and 'winter' conditions are applied demonstrates the mechanism of failure, but is not reliably predictive. In particular, it does not account for the inherent variability in natural climate, in which, for example, a wet summer might be followed by a relatively dry winter, resulting in a small or insignificant annual variation in pore water pressures.

An alternative approach is to apply rainfall infiltration as a surface flow, and simulate plant root abstraction by removal of water from within a defined depth of the model representing a plant root zone (e.g. Rouainia et al., 2009; Briggs, 2010, 2011). This approach generates the pore water 
pressures in the surface zone, replacing the need to impose them onto the model. However, to generate realistic pore water pressure changes in this way, there is a need to understand and replicate the correct physical processes, such as infiltration, runoff and plant water abstraction. These processes are sensitive to model parameters such as the soil permeability and the shape of the soil water retention curve. Rouainia et al. (2009) describe differences between their model and field observations that they suggest are due to uncertainties concerning the bulk soil permeability, including clay cracking, and its effect on infiltration. One of the slopes they model is the site described in this paper.

Climate boundary models are needed to explore and understand the impact that climate change will have on slope instability mechanisms, but must be able to replicate cycles of pore water pressure reliably before they can be used for this purpose (Smethurst et al., 2006; Rouainia et al., 2009; Clarke \& Smethurst, 2010). There are few high-resolution, long-term measurements of changes in pore water pressures and soil water content in the surface zone of clay slopes: hence there is little information enabling these changes to be linked to climatic conditions. This paper presents six years of water content and pore water pressure observations at a London Clay cutting near Newbury, UK, and shows how they can be related to the measured climate using a water balance model. A 40-year run of rainfall data is used to characterise the approximate return periods of the observed variations in soil water conditions.

\section{SITE DESCRIPTION AND INSTRUMENTATION}

The site is located on the A34 Newbury bypass in Southern England (Fig. 1; UK Ordnance Survey grid reference SU455652), and is described in detail in Smethurst et al. (2006). The instrumented slope section is $8 \mathrm{~m}$ high and $28 \mathrm{~m}$ long (Fig. 2), and was constructed in 1997. The cutting is in London Clay, which is about $20 \mathrm{~m}$ thick, and naturally weathered to $2 \cdot 5-3.0 \mathrm{~m}$ below original ground level. After the cutting was excavated, up to $0.4 \mathrm{~m}$ of topsoil was placed over the cut London Clay surface to permit vegetation growth on the slope. The vegetation is primarily rough grass and herbs with shrubs. At the start of the study in 2003, the

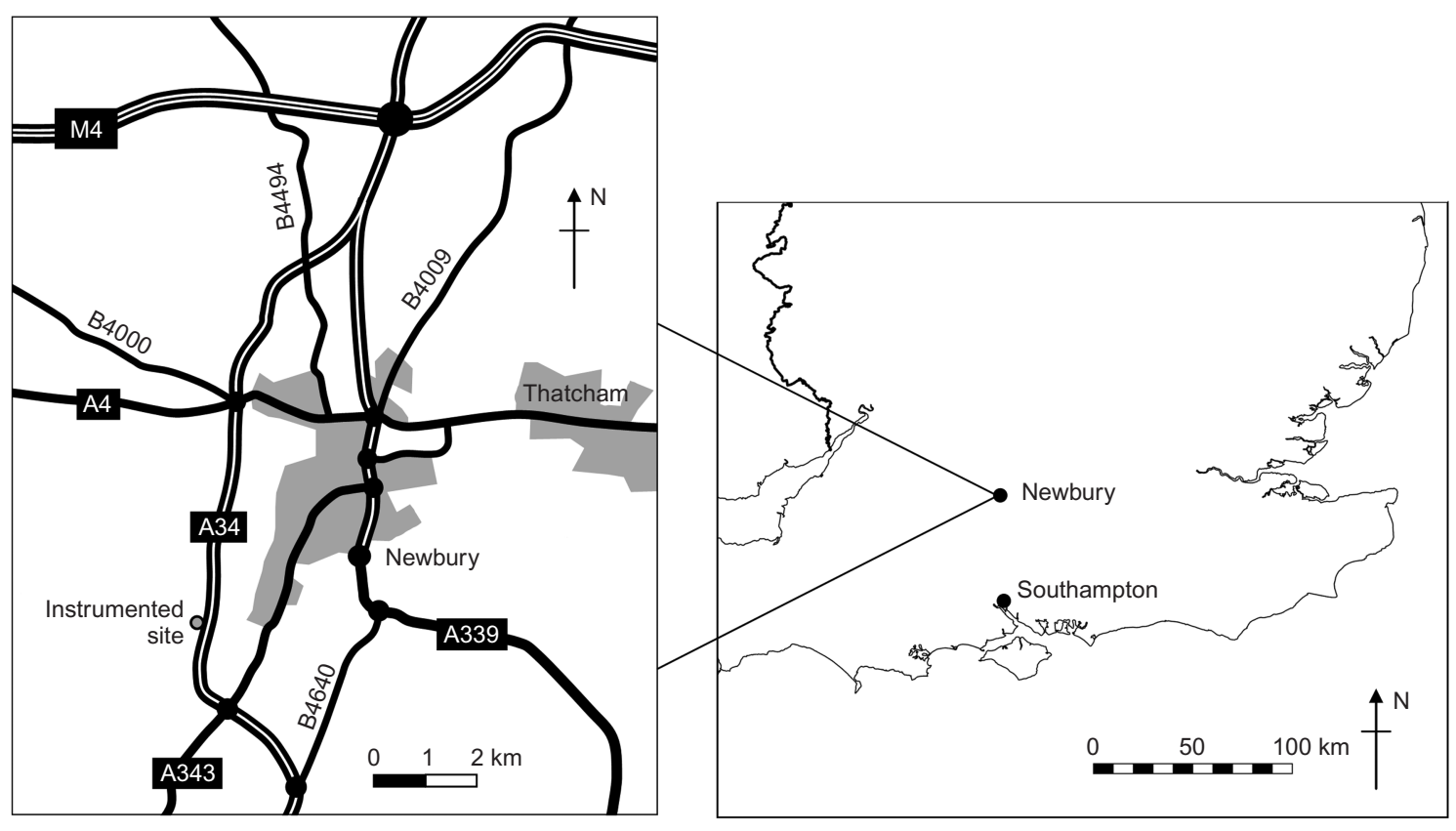

Fig. 1. Location of the Newbury site (coast outline reproduced from Ordnance Survey map data by permission of the Ordnance Survey (C) Crown copyright 2001)

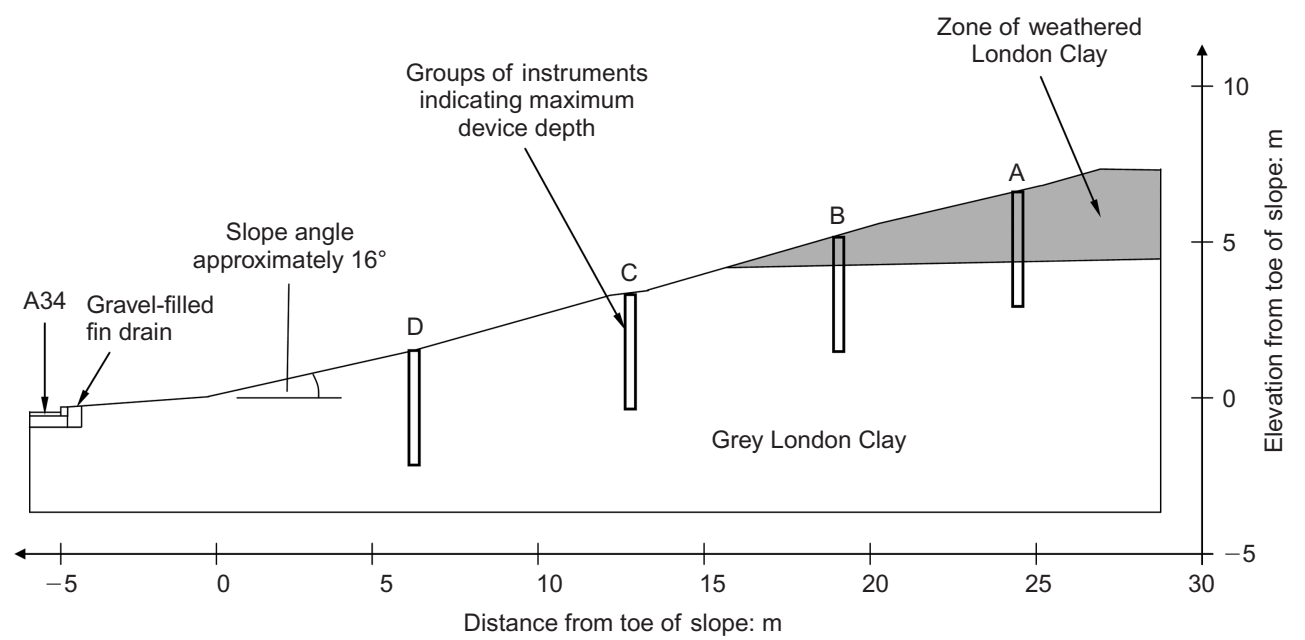

Fig. 2. Cross-section through the instrumented slope 
vegetation was generally less than $0.5 \mathrm{~m}$ high, but many shrubs were approaching $1.5-2.0 \mathrm{~m}$ in height by the beginning of 2009. Mature beech, oak and silver birch trees fringe the top of the slope.

The London Clay at the site is predominantly a stiff grey clay, but contains bands of silty clay up to $50 \mathrm{~mm}$ thick and occasional flints. The weathered clay is spatially very variable, even over short distances, changing from a stiff orange-brown clay to a clayey sandy silt, as described by Perry et al. (2000). Laboratory-measured values of hydraulic conductivity, dry unit weight and plasticity index for the London Clay at the site are given in Table 1. In situ measurements of permeability, determined from borehole bail-out tests, were typically one to two orders of magnitude larger, owing to the effects of anisotropy and fabric (including silt partings and fissures) that were not fully captured in the laboratory tests. The borehole bail-out tests were carried out in May 2003, in unlined boreholes extending to depths of $2.0 \mathrm{~m}$ below ground level.

The soil water retention relationship for London Clay given by Croney (1977) is shown in Fig. 3. This was determined using a combination of a suction plate (for suctions up to about $90 \mathrm{kPa}$ ) and the pressure plate apparatus on small samples of intact clay (Croney, 1977). Owing to the size of samples tested, the relationship in Fig. 3 is likely to represent the water retention behaviour of intact peds of clay, and will not necessarily be representative of the wider fabric of the soil, including the effects of macropores, fissures and cracks.

Instrumentation was installed in 2002-2003 to monitor soil water content, pore water pressure, rainfall, runoff and climatic data required to estimate evapotranspiration. Arrays of time domain reflectrometry (TDR) probes for measuring soil water content, flushable vibrating wire piezometers, water-filled tensiometers and equitensiometers were installed in four groups spaced $6 \mathrm{~m}$ apart down the slope (labelled A-D in Fig. 2). The sensors were installed at depths between $0.3 \mathrm{~m}$ and $3.5 \mathrm{~m}$, at intervals of $0.15,0.3$ or $0.5 \mathrm{~m}$. Table 2 summarises the sensor types and the depths at which they were installed. A climate station was placed on the slope to record air temperature, humidity, wind speed and solar radiation in order to estimate potential evapotranspiration. Rainfall, surface runoff and interflow (i.e. flow of water

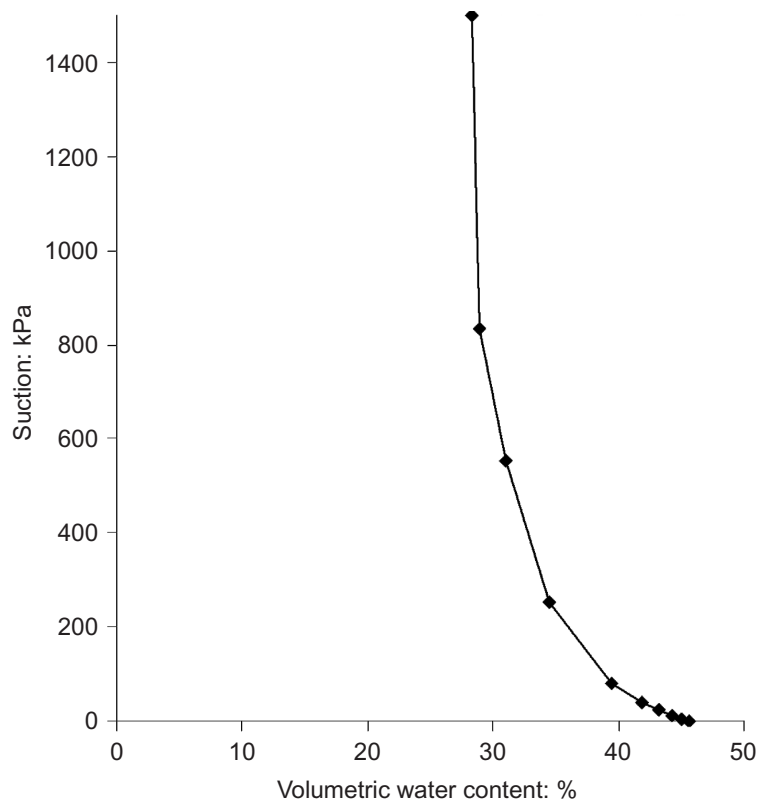

Fig. 3. Soil water retention drying curve for the London Clay, redrawn from Croney (1977) on a linear scale of suction, up to the plant-wilting point $(1500 \mathrm{kPa})$

through the topsoil) were measured using a rain gauge and an interceptor drain cut to $350 \mathrm{~mm}$ depth across the face of the slope.

Aluminium access tubes for a neutron probe were installed adjacent to the datalogged sensors to enable point measurements of water content. A Wallingford neutron probe (Bell, 1987), calibrated against samples for which the water content was determined gravimetrically (Smethurst et al., 2006), was used to measure soil water profiles at approximately two-monthly intervals over parts of the measurement period.

RAINFALL AND POTENTIAL EVAPOTRANSPIRATION

Rainfall is simple to measure. It can be very site specific, but long records are available for many parts of the UK.

Table 1. Permeability, unit weight and plasticity index of grey and weathered London Clay at the Newbury site

\begin{tabular}{|c|c|c|c|c|}
\hline \multirow[t]{2}{*}{ Property } & \multicolumn{2}{|c|}{ Grey London Clay } & \multicolumn{2}{|c|}{ Weathered London Clay } \\
\hline & Range & Average & Range & Average \\
\hline $\begin{array}{l}\text { Saturated vertical permeability, from triaxial tests: } \mathrm{m} / \mathrm{s} \\
\text { Saturated permeability, from borehole bail-out tests: } \mathrm{m} / \mathrm{s} \\
\text { Dry unit weight, } \gamma_{\mathrm{d}}: \mathrm{kN} / \mathrm{m}^{3} \\
\text { Plasticity index, } I_{\mathrm{D}}: \%\end{array}$ & $\begin{array}{c}3 \cdot 9 \times 10^{-11} \text { to } 6 \cdot 6 \times 10^{-10} \\
2 \cdot 3 \times 10^{-9} \text { to } 4 \cdot 4 \times 10^{-9} \\
13 \cdot 2 \text { to } 15 \cdot 2 \\
32 \cdot 5 \text { to } 36 \cdot 4\end{array}$ & $\begin{array}{l}2.3 \times 10^{-10} \\
3 \cdot 7 \times 10^{-9} \\
14 \cdot 6 \\
34 \cdot 8\end{array}$ & $\begin{array}{c}5 \cdot 0 \times 10^{-10} \text { to } 1 \cdot 6 \times 10^{-9} \\
3.6 \times 10^{-8} \text { to } 5 \cdot 0 \times 10^{-8} \\
13 \cdot 2 \text { to } 16 \cdot 2 \\
31 \cdot 7^{*}\end{array}$ & $\begin{array}{c}8.7 \times 10^{-10} \\
4.3 \times 10^{-8} \\
16 \cdot 0 \\
31 \cdot 7^{*}\end{array}$ \\
\hline
\end{tabular}

* Only one of five samples tested for the weathered London Clay exhibited plasticity; the remainder were a silty sand.

Table 2. Summary of pore water pressure/suction and water content sensors installed

\begin{tabular}{|c|c|c|c|c|}
\hline Measurement & Type of instrument & Quantity and depths & Measuring range/accuracy & Source/references \\
\hline Soil suction & Tensiometer & 10 , at depths of $0.3,0.6$ and $0.9 \mathrm{~m}$ & Matric suction up to $80 \mathrm{kPa}$ & $\begin{array}{l}\text { Delta-T Devices Ltd, } \\
\text { Cambridge, UK }\end{array}$ \\
\hline $\begin{array}{l}\text { Soil suction/pore } \\
\text { water pressure }\end{array}$ & $\begin{array}{l}\text { Flushable } \\
\text { piezometer }\end{array}$ & $\begin{array}{l}16 \text {, at depths of } 1 \cdot 0,1 \cdot 5,2 \cdot 0,2 \cdot 5 \text { and } \\
3 \cdot 0 \mathrm{~m}\end{array}$ & Pore pressure between 300 and $-80 \mathrm{kPa}$ & $\begin{array}{l}\text { Soil Instruments Ltd, } \\
\text { Uckfield, UK }\end{array}$ \\
\hline Soil suction & Equitensiometer & 3 , all at $0 \cdot 3 \mathrm{~m}$ depth & $\begin{array}{l}\text { Matric suction up to } 1500 \mathrm{kPa} \text {, over } \\
100 \mathrm{kPa} \text { accuracy } \pm 5 \% \text { of reading }\end{array}$ & $\begin{array}{l}\text { Delta-T Devices Ltd, } \\
\text { Cambridge, UK }\end{array}$ \\
\hline Soil water content & TDR ThetaProbe & $\begin{array}{l}9 \text {, at depths of } 0.3,0.45,0.6,0.9 \text { and } \\
1.5 \mathrm{~m}\end{array}$ & Volumetric water content, $0-50 \%$ & $\begin{array}{l}\text { Delta-T Devices Ltd, } \\
\text { Cambridge, UK }\end{array}$ \\
\hline
\end{tabular}


Fig. 4 compares the monthly rainfall at Newbury for the study period 2002-2008 with the long-term average 19702002 from local rainfall stations within $6 \mathrm{~km}$ of the site. The 1970-2002 annual average rainfall is $875 \mathrm{~mm}$. Rainfall was below average in 2003, 2004 and 2005, whereas 2006, 2007 and 2008 were wetter than average. Fig. 5 shows the cumulative annual rainfall from the long-term records.

Evapotranspiration is a function of the interactions between the elements of the plant-soil-atmosphere system. It depends on plant type, climate, soil characteristics and soil water content, and is difficult to quantify, owing to the variability of these factors. A simplified approach is to assume standard vegetation and soil conditions, so that evapotranspiration is then a function only of climate. This is known as the potential evapotranspiration, typical of that from a well-watered, short, green crop, such as $10-15 \mathrm{~cm}$ long, healthy grass. Potential evapotranspiration was calculated using the Penman-Monteith method (Allen et al., 1994) based on the solar energy recorded at the site, to take into account the influence of slope aspect and shading from the mature trees on the crest of the slope on the energy received. The potential evapotranspiration for the Newbury slope determined in this way was about $25 \%$ less than that calculated for a flat open site nearby (Smethurst et al., 2006).

Daily values of rainfall and potential evapotranspiration for 2003-2008 are shown in Fig. 6. The period included noticeably hot dry summers in 2003 and 2005 and damp summers in 2007 and 2008, which are obvious in the cumulative plots. There is little difference in the annual totals of potential evapotranspiration, which range from $470 \mathrm{~mm}$ in 2003 to $410 \mathrm{~mm}$ in 2007 . In contrast, the variability in annual rainfall is much greater. The winters of 2002-2003 and the summer of 2007 were wetter, and the summers of 2003 and 2005 much drier, than average.

Many slope serviceability and instability problems are associated with exceptional climatic events. The extremes are characterised by the variations in rainfall rather than in evapotranspiration, and for low-permeability clay slopes, soil water contents and pore water pressures are likely to be influenced predominantly by rainfall over longer periods (months rather than days; Loveridge et al., 2010). Cumulative probabilities for the 39-year rainfall record at Newbury were calculated annually, and for one 'winter' (6 months November-April) and two 'summer' periods (6 months

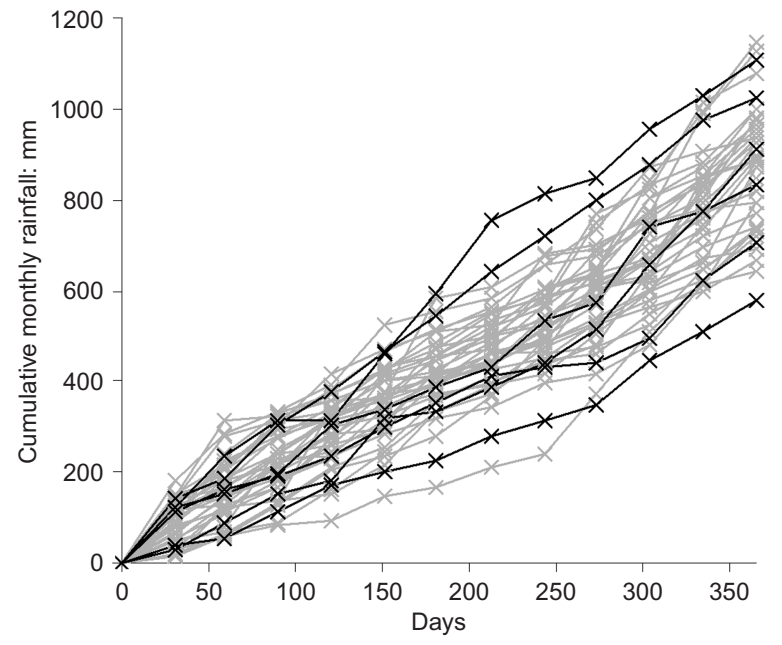

Fig. 5. Variation of measured cumulative rainfall for the Newbury area for 39 years 1970-2008 (years 2003 to 2008 are in bold).

May-October and 3 months June-August). These were used to estimate the return period of events within the record.

Figure 7 and Table 3 show the calculated return periods. The years 2007 and 2008 were wetter than average, with a relative frequency of 1 in 8 years. Conversely, 2003 and 2005 were drier than average, with a relative frequency of around 1 in 10 years. The winter of 2004-2005 was exceptionally dry, with an estimated return period of 1 in 30 years, and the summer of 2007 was exceptionally wet again about the 1 in 30 year event. This demonstrates that the six-year period of slope measurement has captured both average and some moderately extreme periods of climatic conditions.

\section{SOIL WATER BALANCE}

Summer drying occurs as a result of higher temperatures and evaporative demand (expressed as the potential evapotranspiration rate in $\mathrm{mm} /$ day); however, the actual amount of evapotranspiration will depend not only on the evaporative demand but also on the availability (to plants) of water in the soil profile.

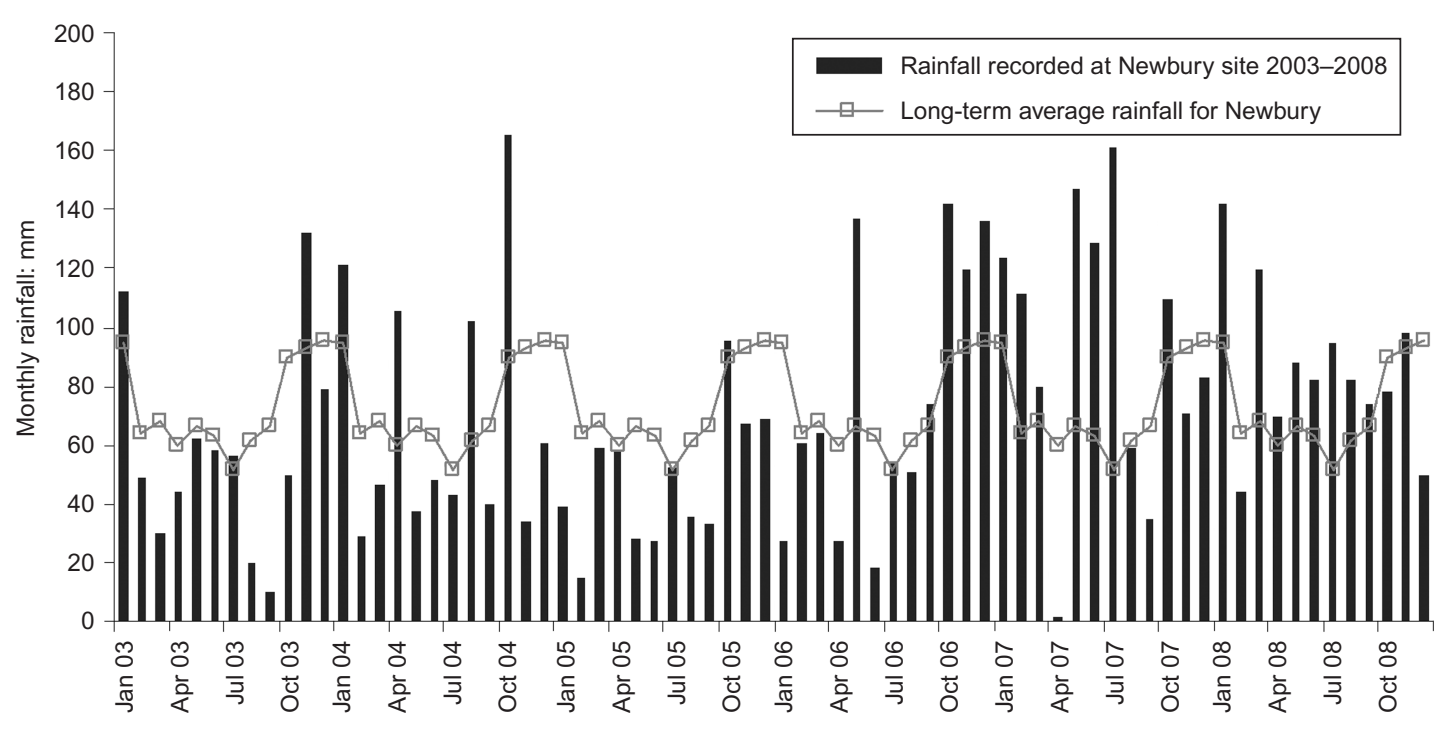

Fig. 4. Monthly rainfall totals measured at the Newbury site 2003-2008 with the long-term 1970-2002 average recorded at stations within $6 \mathrm{~km}$ of the site 


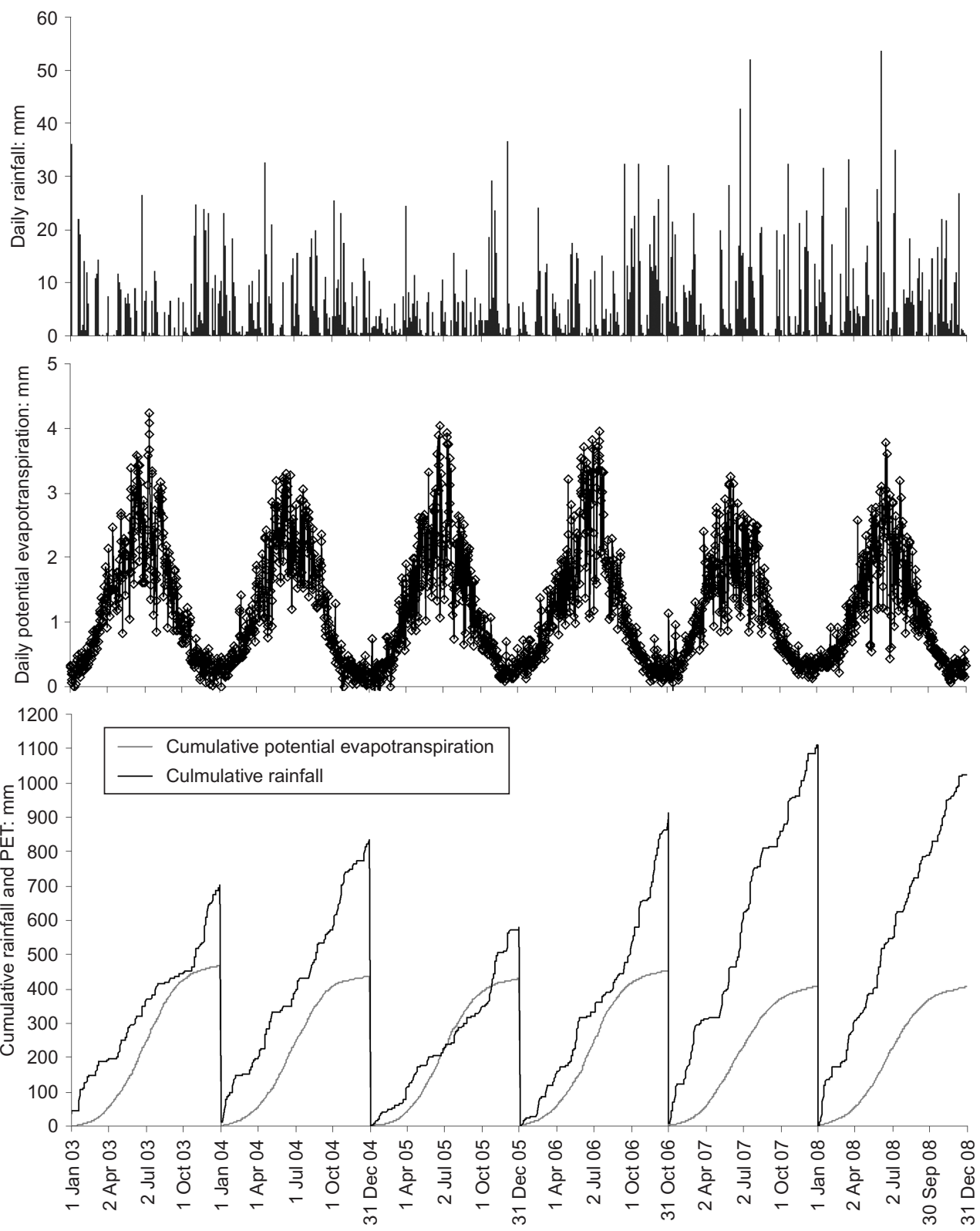

Fig. 6. Measured daily total and cumulative rainfall and potential evapotranspiration (PET)

A one-dimensional water balance calculation based on the CROPWAT software (Clarke et al., 1998) was used to link the climate experienced by the Newbury slope and the measured change in soil water contents in 2003 (Smethurst et al., 2006), modelling rainfall infiltration and evapotranspiration from the $0.8 \mathrm{~m}$ deep rooting zone. Soil drying is calculated as a soil moisture deficit, or SMD, given in millimetres as a volume of water per unit area (the same units as rainfall). A soil with $\mathrm{SMD}=0$ is at 'field capacity', that is, at the equilibrium water content of soil free to drain downwards under gravity. Water is held in the soil by capillary action: hence field capacity is a function of pore size. An intact clay soil would probably be saturated at field capacity, but the structured nature of many stiff clays allows air to be present in larger fissures and voids.

Removal of water by plant evapotranspiration is restricted once the water readily available to the plants (i.e. that stored in cracks and fissures and larger voids within the soil) has been used. This reduced level of evapotranspiration, known as actual evapotranspiration, occurs because the plants find it progressively more difficult to remove water at the potential rate from drying intact clay soil. The plants generate increasing suctions as the water is removed, as measured in the rooting zone by the mid-summer of a typical year.

The water balance model, which includes the calculation of actual evapotranspiration, is described mathematically in the Appendix. The model considers only one-dimensional vertical flow and storage of water within the root zone (the top $0.8 \mathrm{~m}$ of the profile). This ignores percolation into and draw-up of water from the soil below the root zone and, as the ground slopes, any component of lateral flow. However, as the monitoring results show, the seasonal changes in water content in the soil below the rooting zone are generally small compared with those close to the surface (the shallow vegetation is not able to build up a deep sustained water deficit), and the water balance is able to reproduce the changes in the rooting zone well. This one-dimensional approach is likely to work only for a homogeneous cover of small vegetation, and a uniform soil profile (Smethurst \& Clarke, 2007; Clarke \& Smethurst, 2010). Where the deeper rooting of mature trees needs to be modelled, or changes in soil water content and pore pressures below the rooting zone are needed for analysis of slope stability, a twodimensional finite-element/difference approach has generally been adopted (e.g. Rouainia et al., 2009; Briggs, 2010). 


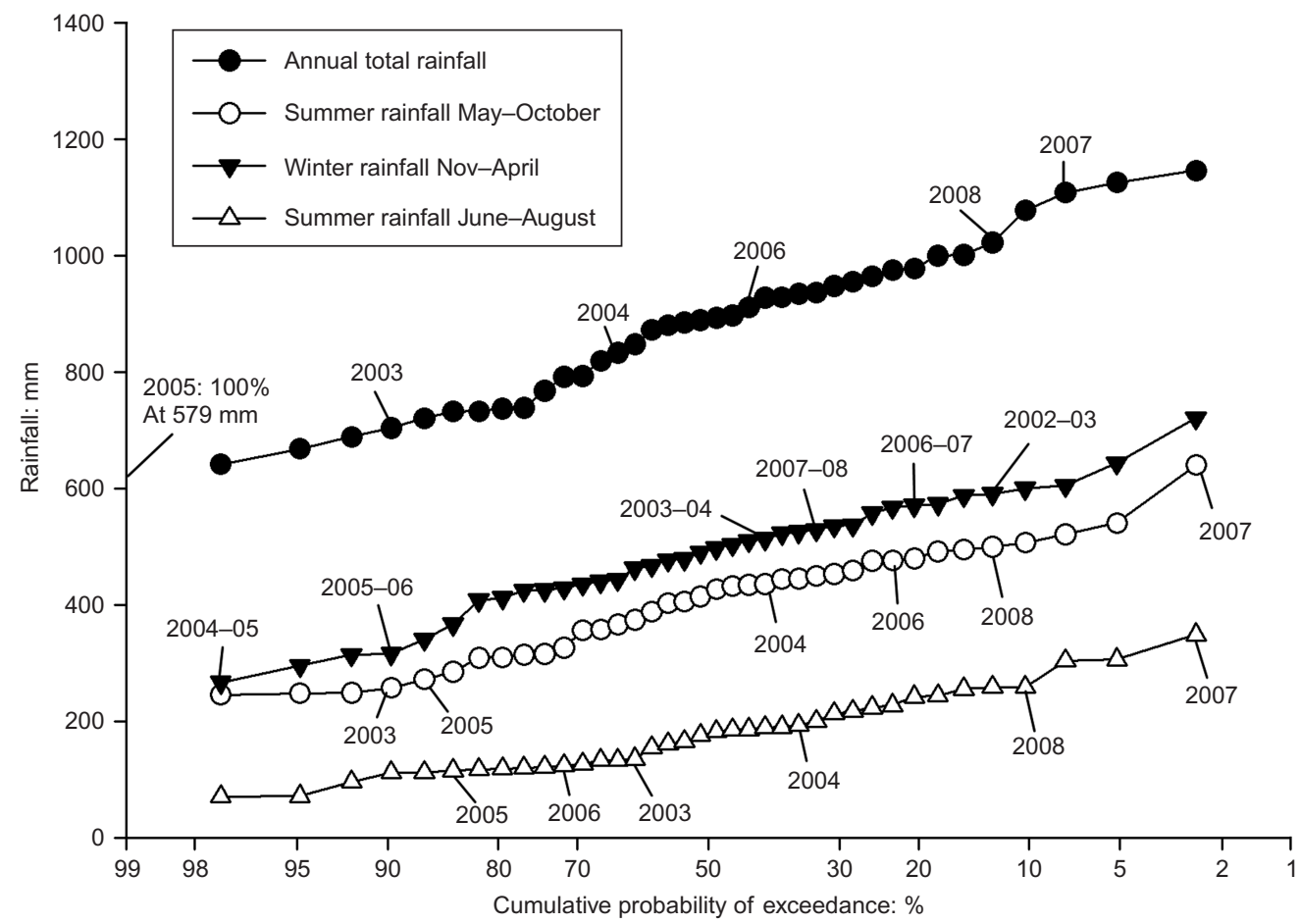

Fig. 7. Cumulative probability of annual, winter (November-April) and summer (both six-month MayOctober and three-month June-August) rainfall totals determined from the 39-year rainfall record for Newbury. The average year is the $\mathbf{5 0 \%}$ position on the graph. Significantly wet years are plotted as a low cumulative probability, and significantly dry years as a high cumulative probability, that is, the 1 in 20 wet year is plotted at the 5\% level, and the 1 in 20 dry year is plotted at the $95 \%$ level

Table 3. Return periods for annual, winter and summer rainfall totals determined from 39 year set of rainfall record for Newbury

\begin{tabular}{|c|c|c|c|c|c|c|c|}
\hline Annual total & Year & 2003 & 2004 & 2005 & 2006 & 2007 & 2008 \\
\hline & $\begin{array}{l}\text { Rainfall: } \mathrm{mm} \\
\text { Cumulative probability of exceedance: \% } \\
\text { Return period (amount of rainfall is } \\
\text { exceeded every): years }\end{array}$ & $\begin{array}{c}703 \\
89 \cdot 7 \\
35 \text { in } 39 \\
(\sim 9 \text { in } 10)\end{array}$ & $\begin{array}{c}833 \\
64 \cdot 1 \\
25 \text { in } 39 \\
(\sim 5 \text { in } 8)\end{array}$ & $\begin{array}{c}580 \\
100 \\
39 \text { in } 39\end{array}$ & $\begin{array}{c}911 \\
43 \cdot 6 \\
17 \text { in } 39\end{array}$ & $\begin{array}{c}1109 \\
7 \cdot 7 \\
3 \text { in } 39\end{array}$ & $\begin{array}{c}1023 \\
12 \cdot 8 \\
5 \text { in } 39 \\
(\sim 1 \text { in } 8)\end{array}$ \\
\hline \multirow[t]{2}{*}{$\begin{array}{l}\text { Winter rainfall } \\
\text { (Nov-April) }\end{array}$} & Year & $2002-2003$ & $2003-2004$ & 2004-2005 & $2005-2006$ & $2006-2007$ & $2007-2008$ \\
\hline & $\begin{array}{l}\text { Rainfall: } \mathrm{mm} \\
\text { Cumulative probability of exceedance: \% } \\
\text { Return period (amount of rainfall is } \\
\text { exceeded every): years }\end{array}$ & $\begin{array}{c}591 \\
12 \cdot 8 \\
5 \text { in } 39 \\
(\sim 1 \text { in } 8)\end{array}$ & $\begin{array}{c}513 \\
41 \cdot 0 \\
16 \text { in } 39 \\
(\sim 2 \text { in } 5)\end{array}$ & $\begin{array}{c}267 \\
97 \cdot 4 \\
38 \text { in } 39\end{array}$ & $\begin{array}{c}316 \\
89 \cdot 7 \\
35 \text { in } 39 \\
(\sim 7 \text { in } 8)\end{array}$ & $\begin{array}{c}571 \\
20 \cdot 5 \\
8 \text { in } 39 \\
(\sim 1 \text { in } 5)\end{array}$ & $\begin{array}{c}528 \\
33 \cdot 3 \\
13 \text { in } 39\end{array}$ \\
\hline \multirow{2}{*}{$\begin{array}{l}\text { Summer rainfall } \\
\text { (May-Oct) }\end{array}$} & Year & 2003 & 2004 & 2005 & 2006 & 2007 & 2008 \\
\hline & $\begin{array}{l}\text { Rainfall: } \mathrm{mm} \\
\text { Cumulative probability of exceedance: \% } \\
\text { Return period (amount of rainfall is } \\
\text { exceeded every): years }\end{array}$ & $\begin{array}{c}257 \\
89 \cdot 7 \\
35 \text { in } 39 \\
(\sim 7 \text { in } 8)\end{array}$ & $\begin{array}{c}436 \\
41 \cdot 0 \\
16 \text { in } 39 \\
(\sim 2 \text { in } 5)\end{array}$ & $\begin{array}{c}272 \\
87 \cdot 2 \\
34 \text { in } 39\end{array}$ & $\begin{array}{c}476 \\
23 \cdot 1 \\
9 \text { in } 39 \\
(\sim 1 \text { in } 4)\end{array}$ & $\begin{array}{c}640 \\
12 \cdot 8 \\
5 \text { in } 39 \\
(\sim 1 \text { in } 8)\end{array}$ & $\begin{array}{c}499 \\
2 \cdot 6 \\
1 \text { in } 39\end{array}$ \\
\hline \multirow{2}{*}{$\begin{array}{l}\text { Summer rainfall } \\
\text { (June-August) }\end{array}$} & Year & 2003 & 2004 & 2005 & 2006 & 2007 & 2008 \\
\hline & $\begin{array}{l}\text { Rainfall: } \mathrm{mm} \\
\text { Cumulative probability of exceedance: \% } \\
\text { Return period (amount of rainfall is } \\
\text { exceeded every): years }\end{array}$ & $\begin{array}{c}135 \\
61 \cdot 5 \\
24 \text { in } 39 \\
(\sim 3 \text { in } 5)\end{array}$ & $\begin{array}{c}194 \\
35 \cdot 9 \\
14 \text { in } 39 \\
(\sim 7 \text { in } 20)\end{array}$ & $\begin{array}{c}115 \\
84 \cdot 6 \\
33 \text { in } 39 \\
(\sim 17 \text { in } 20)\end{array}$ & $\begin{array}{c}124 \\
71 \cdot 8 \\
28 \text { in } 39 \\
(\sim 7 \text { in } 10)\end{array}$ & $\begin{array}{c}349 \\
2 \cdot 56 \\
1 \text { in } 39\end{array}$ & $\begin{array}{c}259 \\
10 \cdot 26 \\
4 \text { in } 39 \\
(\sim 1 \text { in } 10)\end{array}$ \\
\hline
\end{tabular}

A daily water balance calculation was carried out for the entire six-year monitoring period, giving the variation in SMD over time shown in Fig. 8(a). An SMD develops each summer, and returns to zero during the winter. The largest values of calculated SMD occurred in 2003 and 2005, and only small values were calculated for the wet summers of 2007 and 2008.

Figure 8(b) shows the calculated daily values of actual 


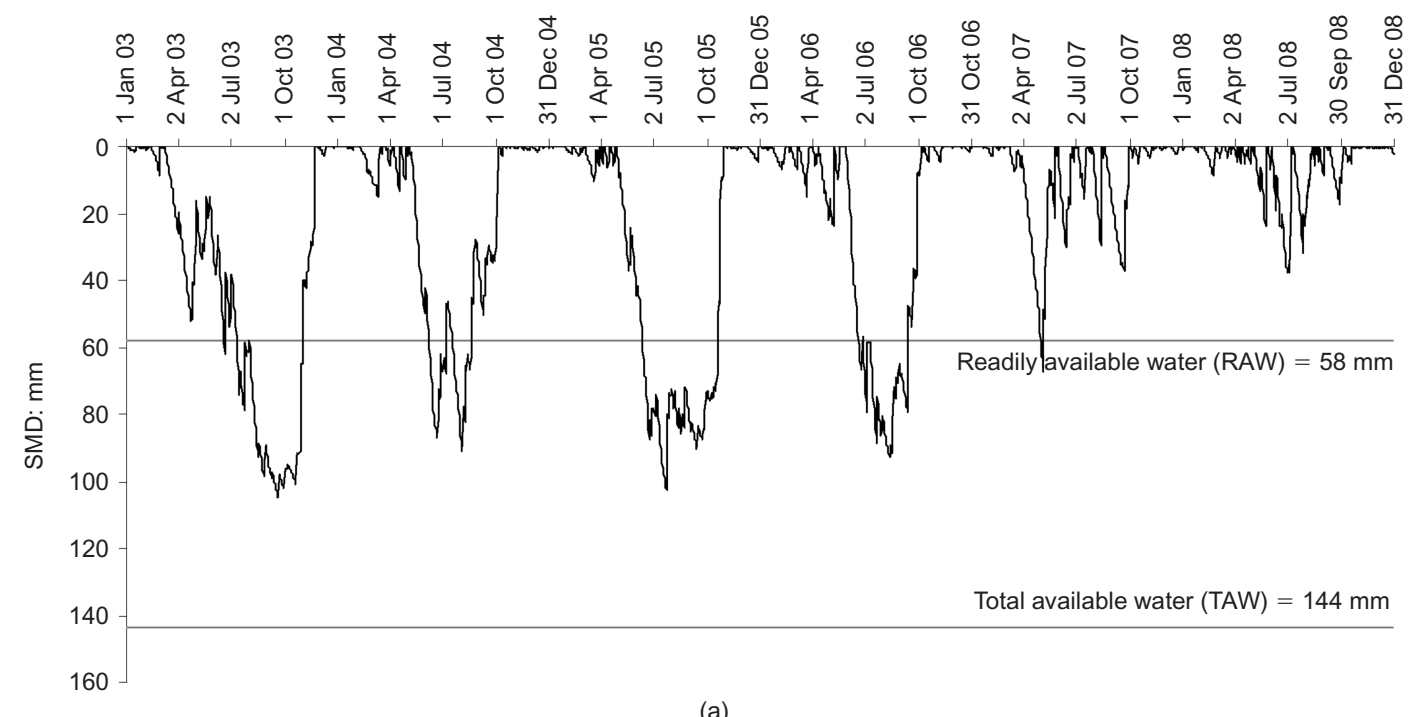

(a)

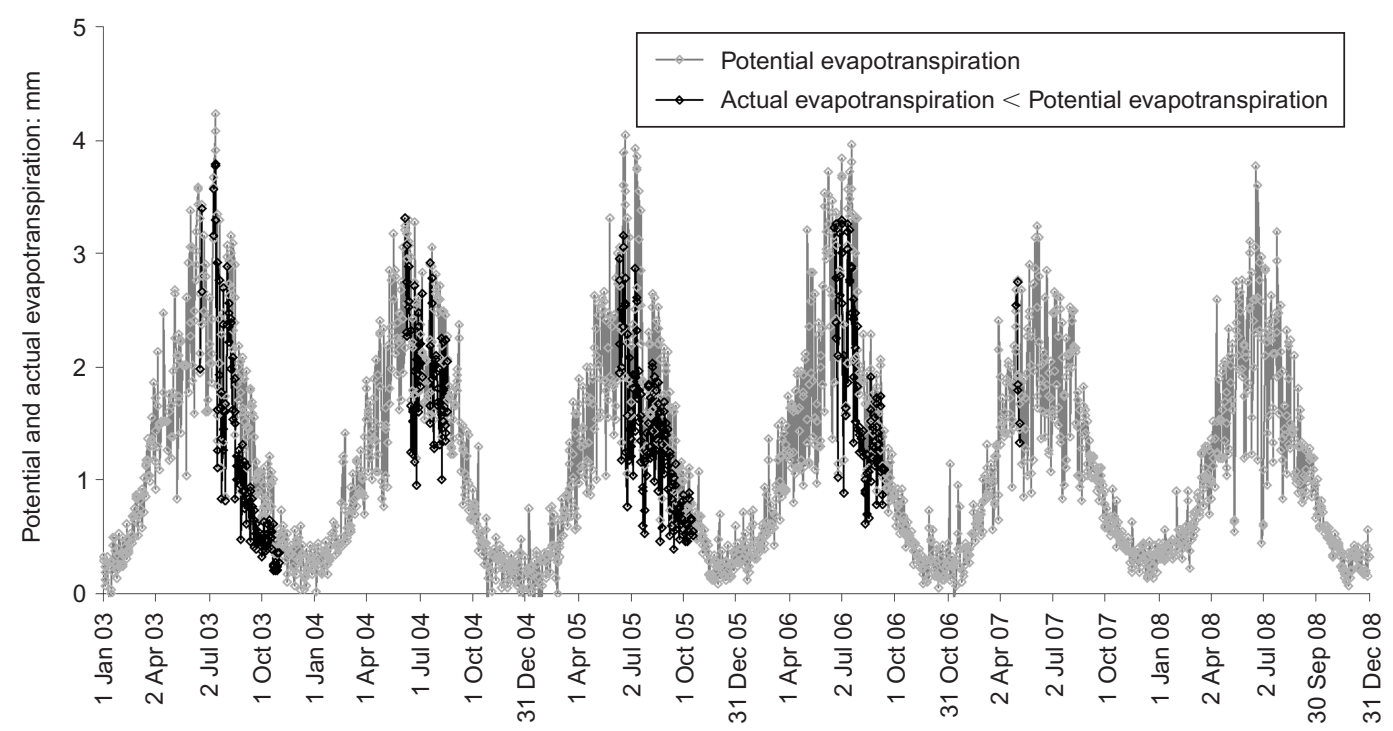

(b)

Fig. 8. (a) Calculated soil moisture deficit (SMD); (b) calculated daily potential and actual evapotranspiration

and potential evapotranspiration. Annual totals are given in Table 4, showing that the soil barely dried in the wet summers of 2007 and 2008, and evapotranspiration continued at the potential rate. In drier years, such as 2005, the modelled SMD exceeds the readily available water (RAW) for a long period (130 days), resulting in the daily actual evapotranspiration falling to less than half of the potential rate. With the exception of 2005, the calculated actual annual evapotranspiration varies little from year to year, remaining close to $410 \mathrm{~mm} / \mathrm{year}$ (Table 4). This reinforces the earlier assertion that the observed changes in soil water content are dictated mainly by variations in rainfall.

\section{Runoff}

The daily runoff totals from both the water balance calculation and the flow gauge are shown in Fig. 9. The water balance model assumes that runoff from the slope occurs only if SMD $=0$. Analysis of the runoff totals in sixmonth 'summer' and 'winter' periods from installation through to the summer of 2006 (Table 5) shows that the flow gauge recorded about half the runoff calculated by the model. The ratio of measured to calculated runoff reduces dramatically after the summer of 2006; this is thought to have been due to the gravel collector trench becoming clogged with fines.

Table 4. Annual totals of potential and actual evapotranspiration

\begin{tabular}{l|c|c|c|c|c|c}
\hline & \multicolumn{6}{|c}{ Year } \\
\cline { 2 - 7 } & 2003 & 2004 & 2005 & 2006 & 2007 & 2008 \\
\hline Potential evapotranspiration: mm & 469 & 437 & 430 & 453 & 409 & 407 \\
Actual evapotranspiration: mm & 414 & 412 & 368 & 418 & 408 & 407 \\
\hline
\end{tabular}




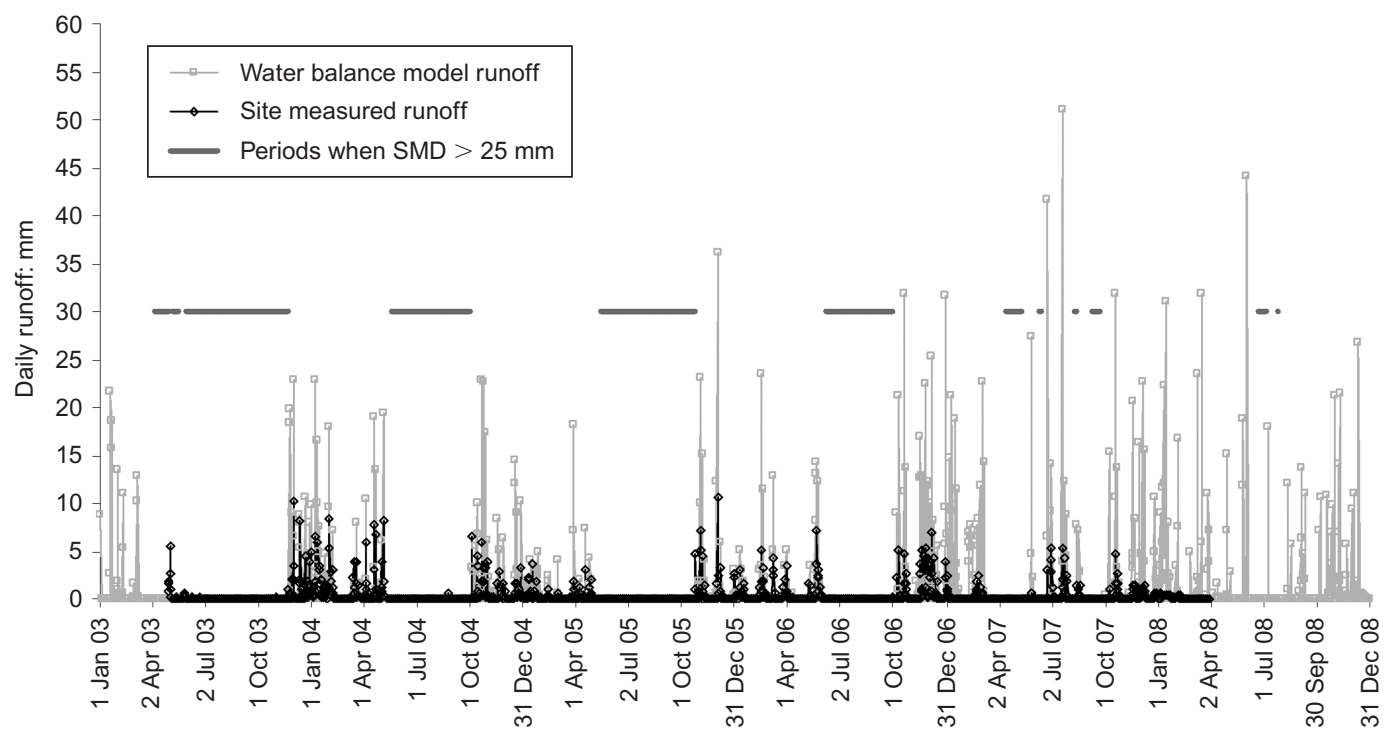

Fig. 9. Daily runoff determined from the water balance model plotted with site-measured runoff

Table 5. Comparison of six-month intervals of runoff measured by the flow gauge and estimated from the water balance calculation, where 'summer' $=$ April-September, and 'winter' = October-March

\begin{tabular}{|c|c|c|c|c|}
\hline Period & $\begin{array}{l}\text { Measured runoff: } \\
\mathrm{mm}\end{array}$ & $\begin{array}{l}\text { Runoff from water } \\
\text { balance model: } \mathrm{mm}\end{array}$ & $\begin{array}{l}\text { Measured runoff/water } \\
\text { balance runoff: } \%\end{array}$ & Notes \\
\hline $\begin{array}{l}\text { Summer 2003 } \\
\text { Winter 2003-2004 } \\
\text { Summer 2004 } \\
\text { Winter 2004-2005 } \\
\text { Summer 2005 } \\
\text { Winter 2005-2006 } \\
\text { Summer 2006 } \\
\text { Winter 2006-2007 } \\
\text { Summer 2007 } \\
\text { Winter 2007-2008 } \\
\text { Summer 2008 }\end{array}$ & $\begin{array}{r}15^{*} \\
140 \\
48 \\
92 \\
11 \\
100 \\
32 \\
108 \\
42 \\
45 \\
1^{\dagger}\end{array}$ & $\begin{array}{r}0 \\
273 \\
76 \\
269 \\
19 \\
215 \\
65 \\
595 \\
224 \\
464 \\
183\end{array}$ & $\begin{array}{l}\mathrm{n} / \mathrm{a} \\
51 \\
63 \\
34 \\
57 \\
46 \\
49 \\
18 \\
18 \\
10 \\
0 \cdot 5\end{array}$ & $\begin{array}{l}\text { Flow gauge readings are much smaller than the } \\
\text { runoff calculated from the water balance model. } \\
\text { It is believed that the gravel cut-off trench had } \\
\text { become clogged with clay fines. }\end{array}$ \\
\hline
\end{tabular}

* Measured runoff starts only at the end of April 2003.

${ }^{\dagger}$ Flow gauge installation flooded and not operating correctly

The significant difference between the calculated and measured runoff is difficult to explain, but probably relates in part to the capture efficiency of the surface runoff interception trench. Furthermore, the trench is located below the $\mathrm{C}$ group of instruments (Fig. 2), and collects water from an area that includes weathered London Clay. A larger water deficit is measured in the weathered soil than is calculated by the water balance, and this greater deficit may account for some of the difference between modelled and measured runoff.

Smethurst et al. (2006) showed that during the summer of 2003, when the soil moisture was in moderate deficit (SMD $>25 \mathrm{~mm}$ ), very little runoff was either measured, or calculated by the water balance model. This continued for the dry summers of 2004, 2005 and 2006 (Fig. 9). Despite the low permeability of the clay, quite substantial rainfall events (e.g. $32 \mathrm{~mm} /$ day) are absorbed by the soil when the SMD is large. This is assisted by clay desiccation cracking and the structured nature of the surface soils, where there are often voids left by animals, roots and decayed organic matter (Weiler \& Naef, 2003), which all provide preferential pathways for water infiltration into the rooting zone. Importantly, the measured runoff data confirm the assumption in the model that rainfall converts to runoff when the SMD is close to zero.

\section{MEASURED SEASONAL VARIATIONS IN SOIL WATER CONTENT AND PORE WATER PRESSURE \\ Soil water content}

Volumetric soil water contents $\left(w_{\mathrm{vol}}=\right.$ volume of water/ total volume) were measured using the TDR ThetaProbe sensors. Fig. 10 shows the seasonal cycling of wetting and drying; in winter, the probes return to a water content close to the point of saturation for London Clay, about $45 \%$ by volume (Croney, 1977).

Figure 10(a) shows the volumetric soil water content measured by the TDR sensors at instrument group A in undisturbed, naturally weathered London Clay. Reductions in water content were observed at $0.3 \mathrm{~m}, 0.45 \mathrm{~m}$ and $0.6 \mathrm{~m}$ depth each year between June and September, reflecting the summer drying period. The drying was smaller, owing to above-average rainfall in the wet summers of 2007 and 2008. Most water content changes occurred in the range $0-0.6 \mathrm{~m}$ below ground level; below this, annual changes were small (typically $\pm 5 \%$ ), even during the dry summers of 2003, 2005 and 2006.

Figure 10(b) shows the volumetric soil water contents measured by the TDR sensors at group $\mathrm{C}$, where the weathered surface layer is absent, and $250 \mathrm{~mm}$ of topsoil cover overlies the grey London Clay. Summer drying is observed at $0.3 \mathrm{~m}$ depth, but changes in water content below 


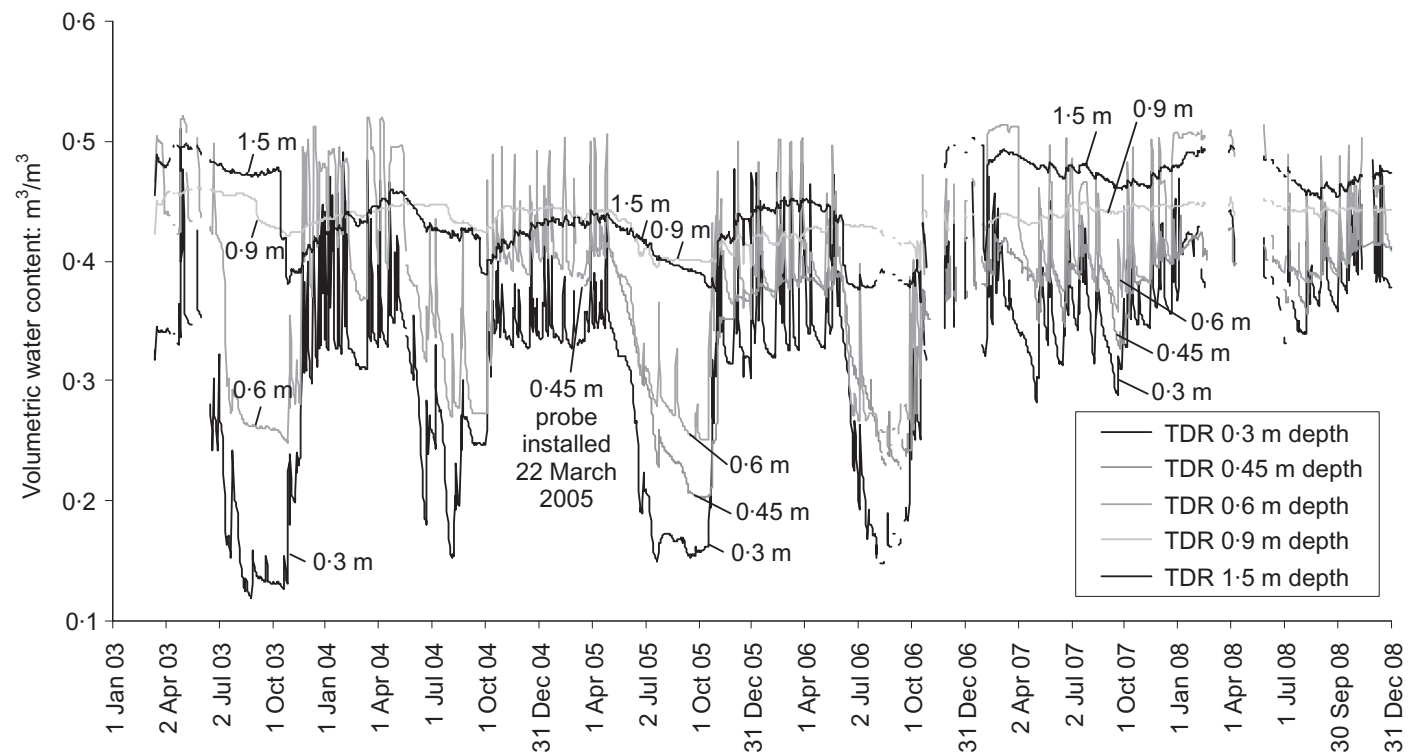

(a)

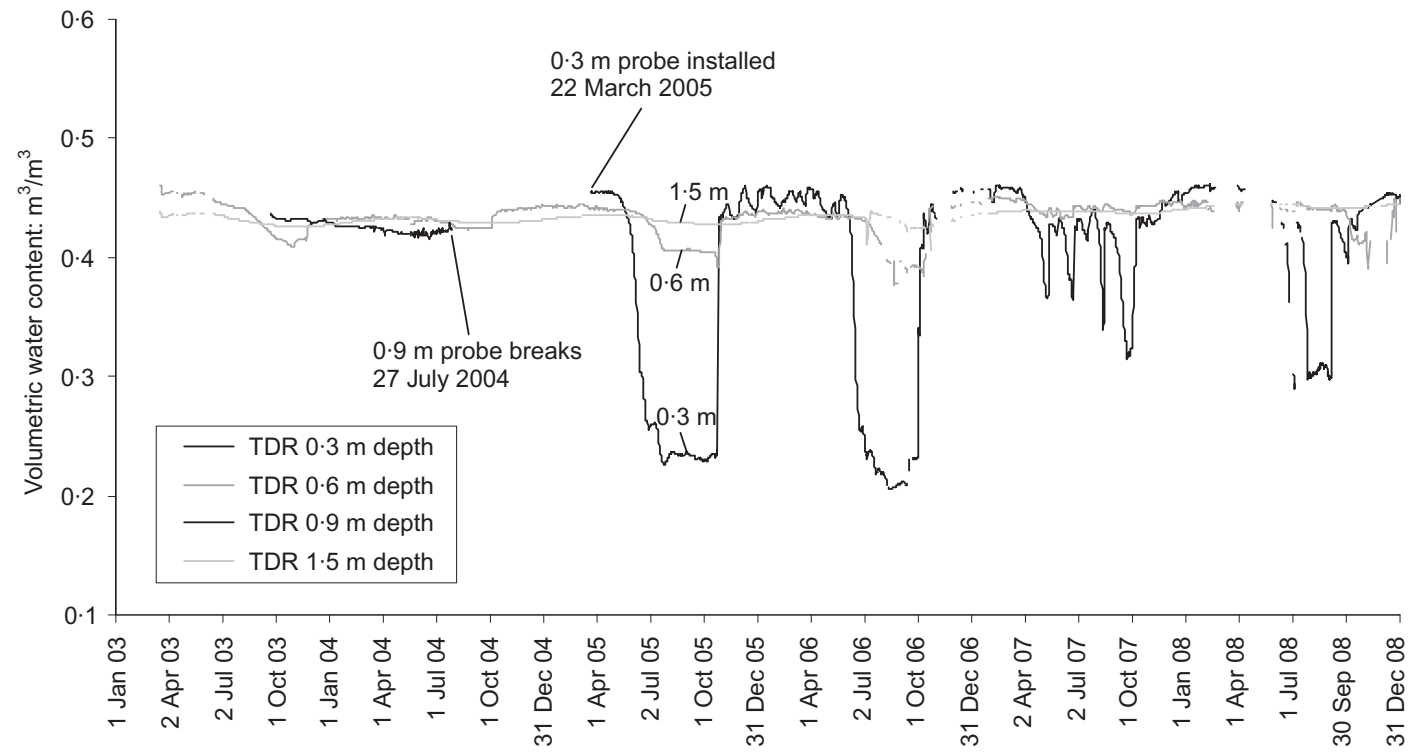

(b)

Fig. 10. Volumetric water content measured using TDR ThetaProbes: (a) within the weathered London Clay at group A; (b) grey London Clay with thin layer of topsoil at group C

$0.3 \mathrm{~m}$ are not as noticeable as at location $\mathrm{A}$ in the weathered clay. Changes in water content are not as rapid at $\mathrm{C}$ as they are at $\mathrm{A}$, which reflects the lower permeability of the stiff grey unweathered London Clay compared with the more silty weathered material.

Soil drying during the summers usually starts in June when the rate of potential evapotranspiration exceeds rainfall. Surface drying (at $0.3 \mathrm{~m}$ depth) typically continues for about $4-6$ weeks, with the water content falling to $15 \%$ by volume. Drying works progressively downwards into the profile with time (Fig. 10), depending on the duration of an absence of significant rainfall. Autumn re-wetting of the surface layer is usually rapid, aided by desiccation cracks and the structured nature of the surface soil, whereas redistribution of rainfall through the deeper profile $(>1.0 \mathrm{~m})$ may take a number of days.

Figure 11 shows vertical profiles of volumetric water content measured using the neutron probe at locations A and C. These show a similar distribution of water content to the TDR sensors, with the major changes in water content occurring over the uppermost metre of soil.

\section{Near-surface pore water pressures and suctions}

Water-filled tensiometers at $0.3 \mathrm{~m}$ and $0.6 \mathrm{~m}$ depth were used to record suctions in the active root zone. Suctions increased rapidly each year around June (Fig. 12), consistent with the drying measured by the TDR probes, but tensiometers can only measure suctions of up to about $75-90 \mathrm{kPa}$ before the water column breaks. The repeated vertical lines in Fig. 11 correspond to refilling and rapid emptying of the tensiometers during dry summers. Suctions at $0.9 \mathrm{~m}$ depth typically took longer to develop, again consistent with the TDR probes, and reached maxima of $65 \mathrm{kPa}$ in October 2003 and $85 \mathrm{kPa}$ in September 2005.

Continuous direct measurement of very high suctions in the field is difficult, although some success has been attained with high-suction tensiometers (Toll et al., 2011). Estimates of large suctions in the rooting zone were obtained at Newbury using equitensiometers, which comprise a TDR ThetaProbe sensor encapsulated in a high air entry ceramic with known water content-suction characteristics. These were installed in each of the instrument groups at $0.3 \mathrm{~m}$ depth. The suction readings from the equitensiometers at 
Volumetric water content: $\%$

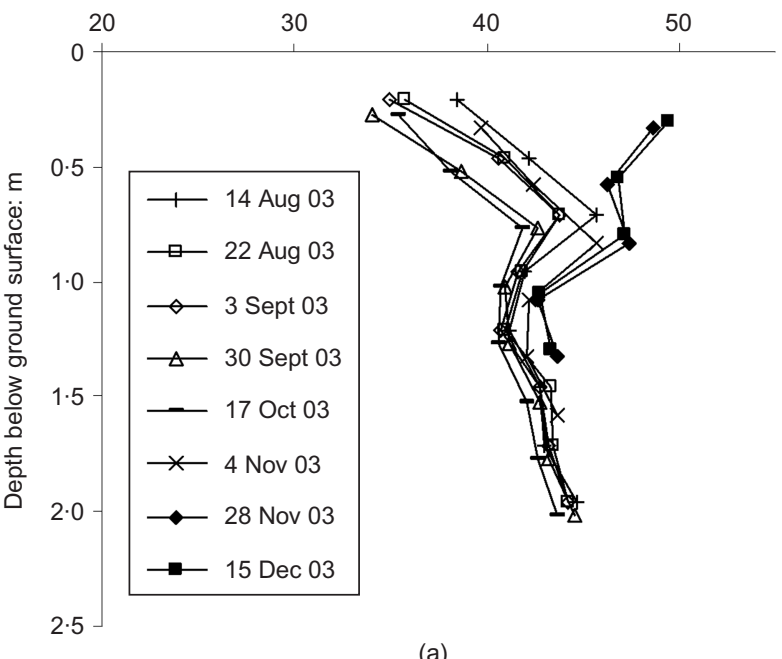

Volumetric water content: \%

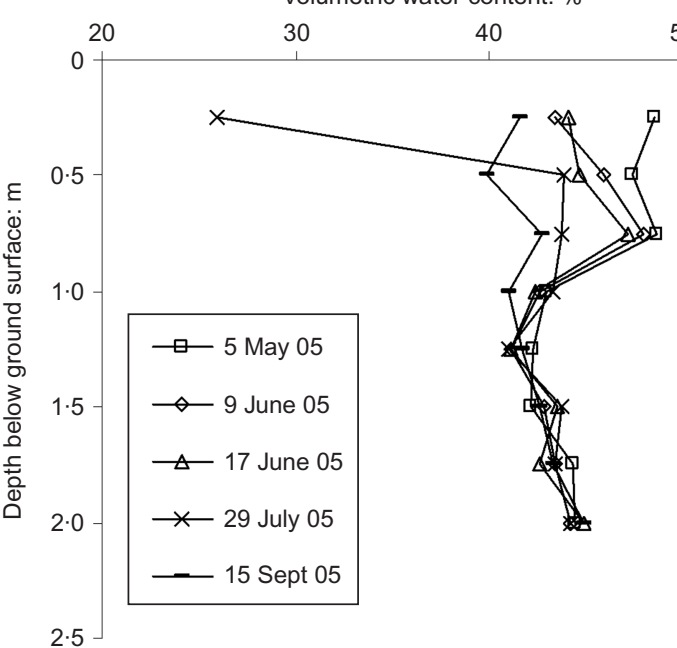

(c)

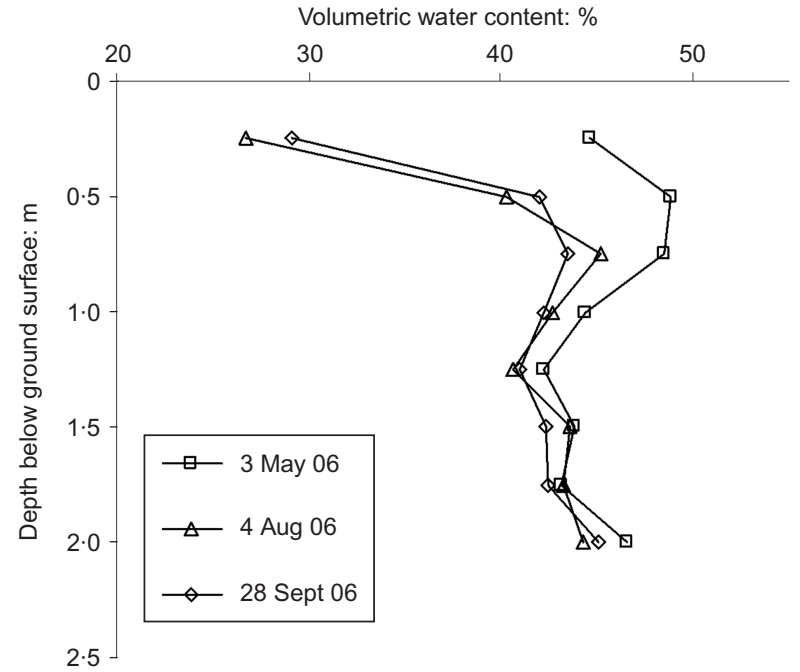

(e)

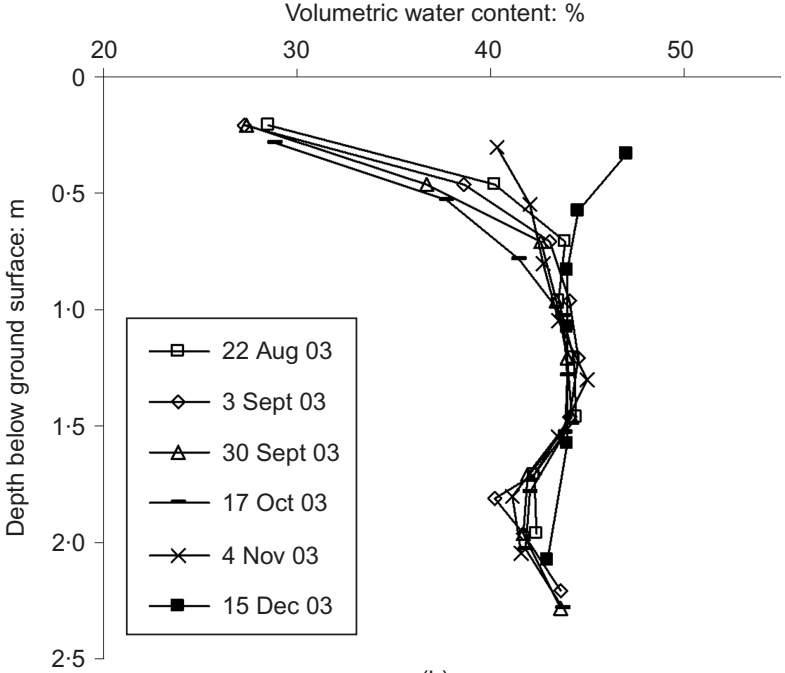

(b)

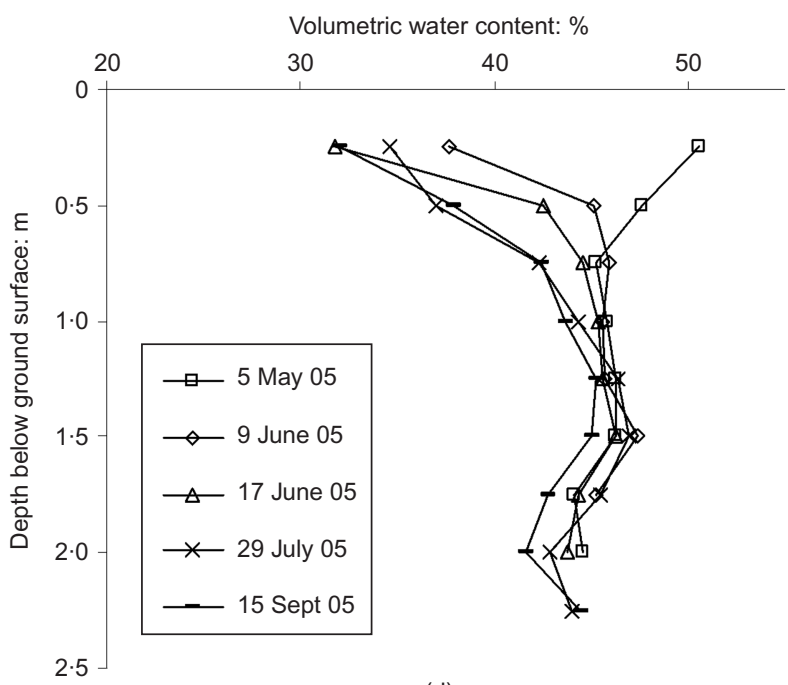

(d)

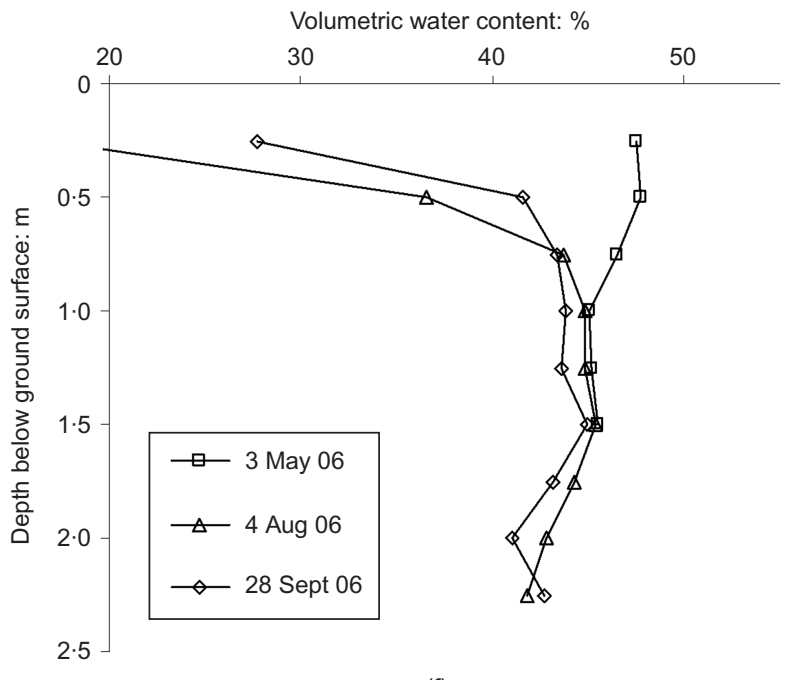

(f)

Fig. 11. Volumetric water content profiles with depth measured using the neutron probe: (a), (c), (e) instrument group A for the years 2003, 2005 and 2006; (b), (d), (f) instrument group C for the years 2003, 2005 and 2006

instrument groups $\mathrm{B}$ and $\mathrm{C}$ are shown in Fig. 13, together with data from the water-filled tensiometers installed at the same depth. The equitensiometers show the development of significantly higher suctions in the surface layer, typically $150 \mathrm{kPa}$ in summer but up to $400 \mathrm{kPa}$ in hot, dry summers at a depth of $0.3 \mathrm{~m}$. The equitensiometer responded more slowly than a conventional tensiometer, with a lag of about three weeks. This may be due to the size of the ceramic and its fairly low permeability, or to small errors in the calibration of the device. 


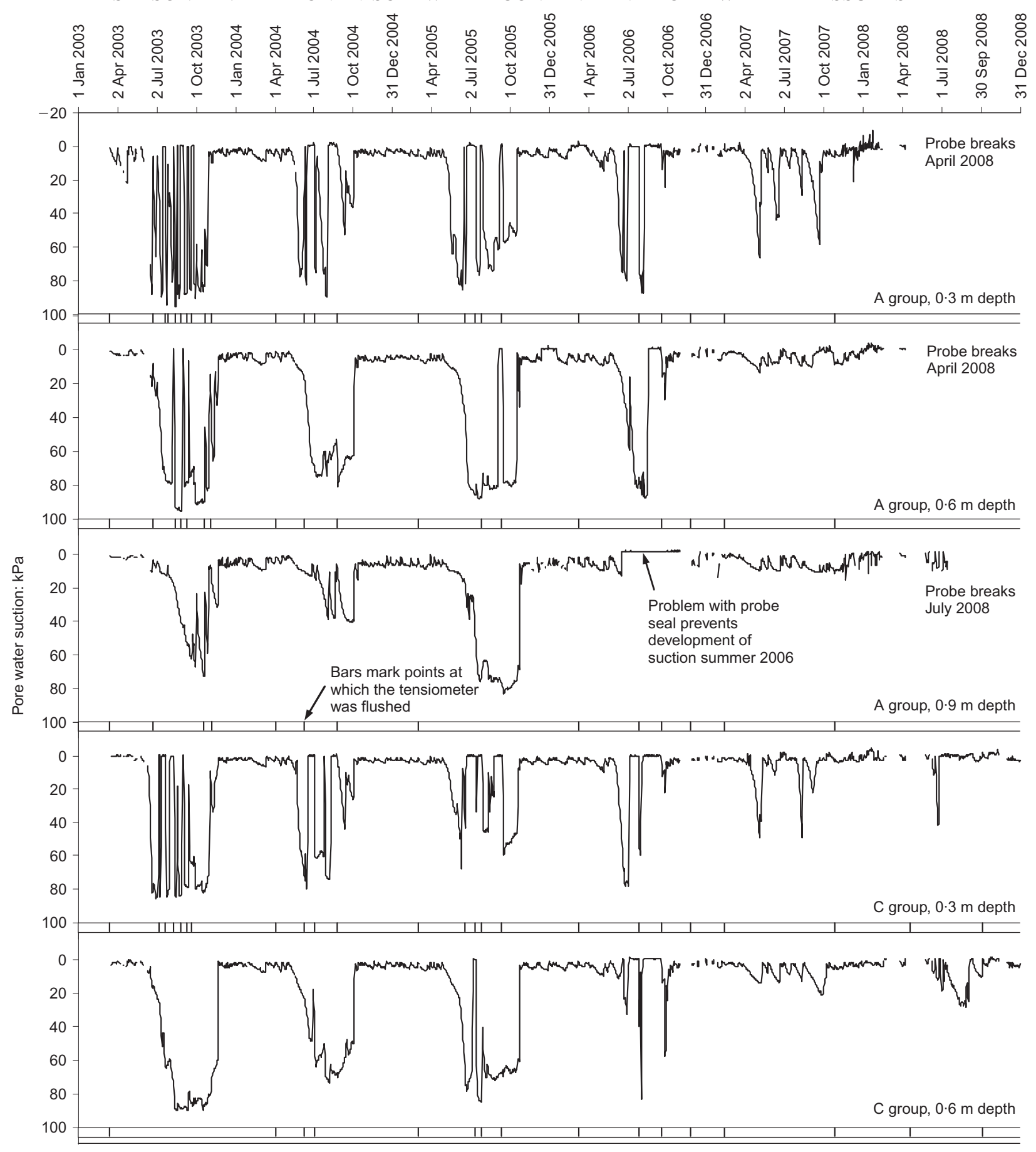

Fig. 12. Soil water suctions measured using tensiometers at instrument groups $A$ and $C$. The vertical bars beneath each tensiometer trace show when the probe was refilled

Suctions persisted for longest during the summers of 2003 and 2005, both of which were relatively dry (Figs 6 and 7). During the very wet summers of 2007 and 2008, both of which have a return period of around 1 in 10 years (Fig. 7), there was a substantial reduction in the maximum suction measured by both the tensiometers and the equitensiometers (although, owing to the lag time described above, if the suctions measured by the tensiometers were small and present only for less than about three weeks, the equitensiometers often did not give a reading at all; Fig. 13).

Pore water pressures and suctions at depths $>1.0 \mathrm{~m}$

Flushable vibrating-wire piezometers were installed between $1.0 \mathrm{~m}$ and $2.5 \mathrm{~m}$ below the surface (Fig. 14). Pore water pressures varied more quickly in the weathered clay at A than in the grey clay with shallow topsoil at $\mathrm{C}$, which is consistent with the pattern of water content measured by the ThetaProbes (Fig. 10). Fig. 15 shows the envelopes of maximum and minimum pore water pressures with depth, at both the $\mathrm{A}$ and $\mathrm{C}$ locations. In dry years, the maximum suctions in the deeper piezometers occurred later in the year (typically by 3 to 4 weeks) than the surface tensiometers. The profiles in Fig. 15 are a composite plot of minimum pore water pressures for the near surface $(<1.0 \mathrm{~m})$ and deeper sensors, although these may not always occur at the same time. Note also that the shallow values are limited to about $-80 \mathrm{kPa}$ as they were obtained from tensiometers, although higher values of suction are likely to have been present in intact peds of the clay soil, as read by the equitensiometers (Fig. 13). 


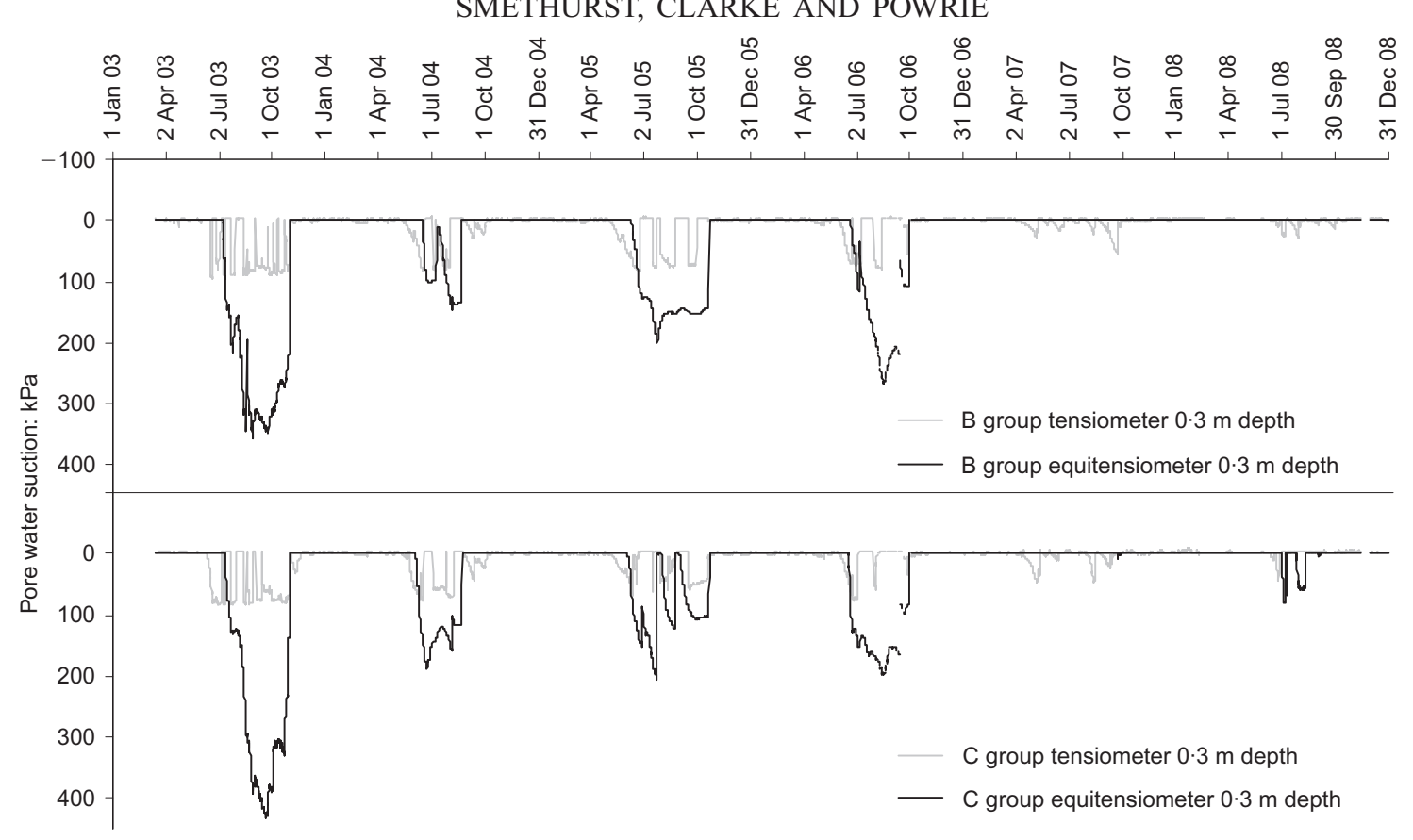

Fig. 13. Suctions determined from equitensiometer and tensiometer probes at $0 \cdot 3 \mathrm{~m}$ depth for instrument groups B and $C$. Note that the equitensiometer does not measure positive pressures, and the reading is set to zero when not in the calibrated suction range

The suctions correlate closely with the measured water contents, with large suctions $(>100 \mathrm{kPa})$ forming in the upper part of the rooting zone for the average and dry summers in which large changes in water content were observed. Maximum suctions reached only about $50 \mathrm{kPa}$ in the wet summers of 2007 and 2008. In the drier summers, at both instrument groups, the profile of suction extends deeper (possibly up to about $3.5 \mathrm{~m}$ beneath the ground surface) than during the wet summers of 2007 and 2008, where only modest suctions extend to about $2 \mathrm{~m}$ depth. The highest pore water pressures (hydrostatic from a water table close to the ground surface) were observed each winter, except in the relatively dry winters of 2004-2005 and 2005-2006. The lower pore water pressures during the two drier winters are more notable at group A than at group $\mathrm{C}$, and may be explained by drainage from the higher-permeability weathered layer requiring a higher level of winter rainfall to keep pore water pressures positive.

While small suctions can extend to around $3.5 \mathrm{~m}$ depth in the grey London Clay during a dry summer, the low permeability of the intact clay prevents a significant draw-up of water (Smethurst et al., 2006), and little change in the water content of the soil is observed below the rooting zone. Water can re-infiltrate through desiccation cracks and larger voids within the soil structure, and it is apparent that the saturated bulk permeability of the soil at this site is high enough to allow fairly rapid winter re-wetting from the surface, causing suctions to be lost at depth. This is consistent with the findings of others for grass-covered clay-cutting slopes (e.g. Greenwood et al., 2001; Vaughan et al., 2004), for which the fairly small extent of summer drying below $1.0 \mathrm{~m}$ depth is insufficient to prevent full re-wetting of the profile during winter. The bulk permeability may be greater than the values obtained from borehole bail-out tests in Table 1, particularly in the surface zone, where preferential flow may occur through desiccation cracks and other macro-voids.

\section{LINK BETWEEN OBSERVED SOIL DRYING AND CLIMATE}

While the SMD may be estimated using a water balance approach, the TDR sensor and neutron probe measurements of water content provide a direct measurement of changes of water content in the soil profile

$$
\mathrm{SMD}=\sum_{i=1}^{n} \Delta w_{\mathrm{vol} i} \times h_{i}
$$

where $n$ is the number of measurement depths within the root zone, $\Delta w_{\text {vol }}$ is the change in volumetric water content, and $h$ is the depth of profile over which the measurement $\Delta w_{\mathrm{vol}}$ is applied. The neutron probe measured the soil water content within a sphere of volume of about $10000 \mathrm{~cm}^{3}$ (radius $14 \mathrm{~cm}$ ) around its radioactive source, and readings were taken at $0.25 \mathrm{~m}$ intervals of depth during visits to the site. The TDR sensors monitored the water content of approximately $100 \mathrm{~cm}^{3}$ of soil every hour, and were spaced as shown in Table 2.

Figure 16 shows the SMD derived from neutron probe measurements and the daily average TDR sensor reading. The water balance calculation is able to replicate the measured changes in soil water, in terms both of the timing of wetting and drying events and of the magnitude of the soil water deficit, although the TDR sensors suggest a $20-30 \%$ greater maximum SMD than the water balance model and neutron probe readings. These differences may be due to the fact that only four TDR sensors were used, whereas the neutron probe measured water contents at eight depths, providing better vertical resolution. The neutron probe also samples a much larger volume of soil.

It was noted previously that the influence of drying during the hot summers extended deeper than the assumed $0.8 \mathrm{~m}$ vegetation rooting depth (Fig. 10). The water balance calculation was repeated for a rooting zone of $1000 \mathrm{~mm}$ (TAW $=180 \mathrm{~mm}$, RAW $=72 \mathrm{~mm}$ ), and plotted with similarly updated calculations of SMD from the neutron probe and TDR sensor readings (Fig. 16(b)). This simulation gave a slightly improved fit to observed field measurements, although differences may also arise from the measurement intervals described above, and from the limitations of the model described earlier. 


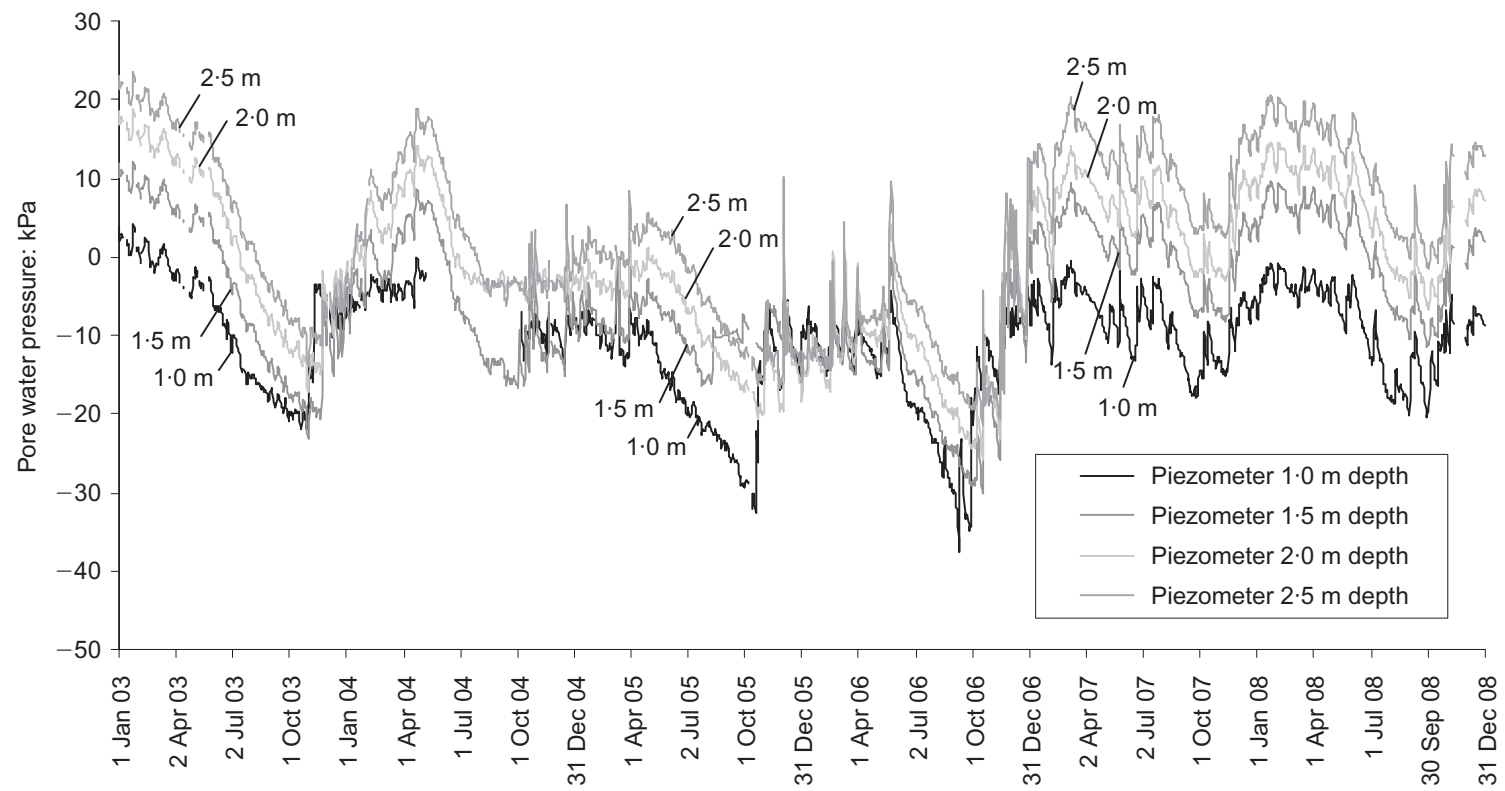

(a)

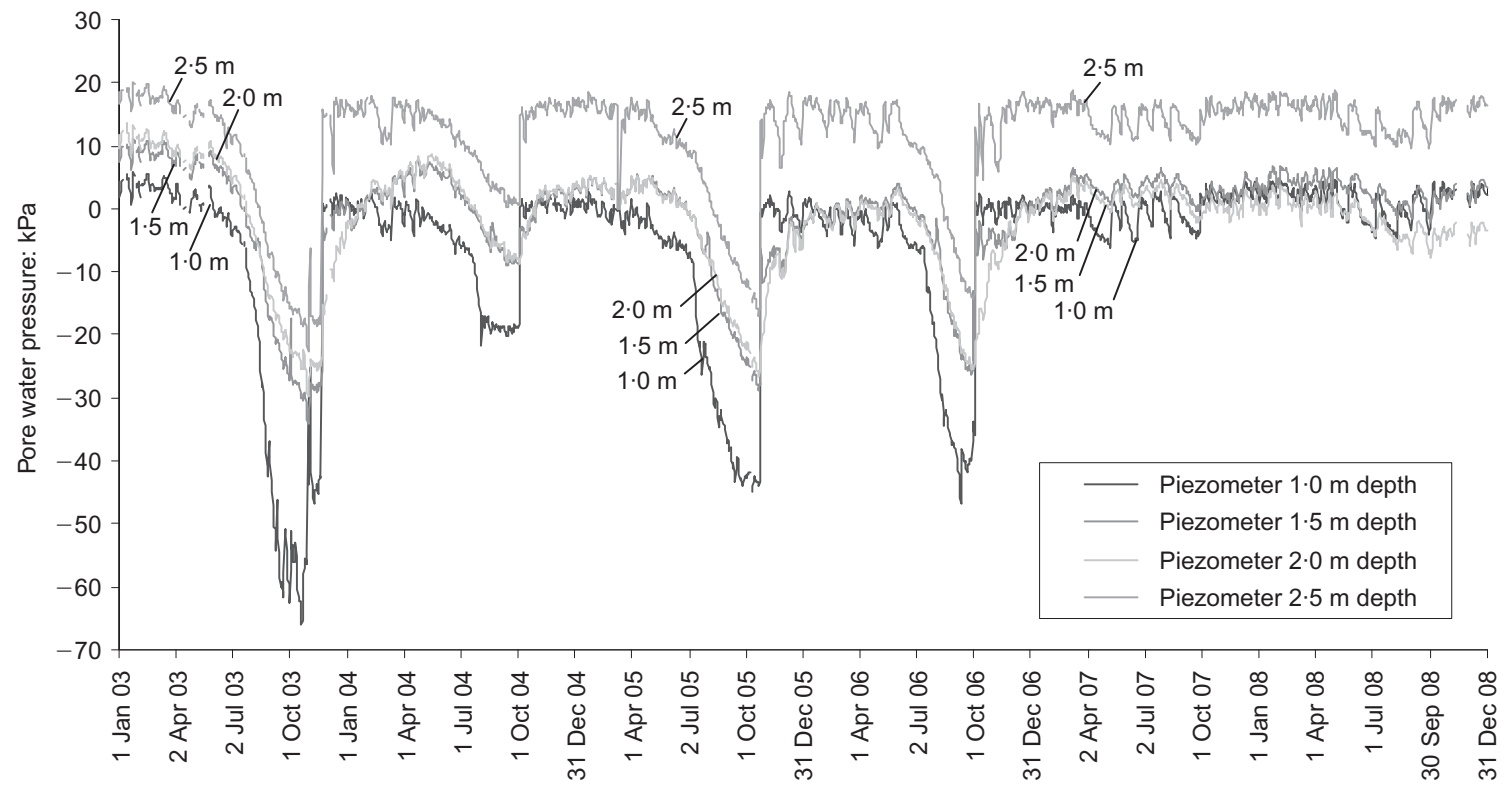

(b)

Fig. 14. Pore water pressures measured using vibrating wire piezometers: (a) within the weathered clay at instrument group A; (b) grey London Clay with thin layer of topsoil at group C

Relating calculated soil moisture deficit to observed pore water pressures

The SMD measured within the root zone can be estimated using readily available climatic data and a relatively small amount of information on the soil and vegetation type (Fig. 16). To test whether the calculated SMD can be used to estimate pore water pressures, water contents measured in the dry summer of 2003 in the unweathered clay at group C shown in Fig 11(b) were converted into pore water suctions using the drying soil water retention curve (SWRC) for London Clay (Fig. 3, after Croney, 1977).

The calculated suction profile is shown in Fig. 17; it follows closely the measured profiles of summer suctions between 2003 and 2008 given in Fig. 15(b). The calculated surface suctions (of about $650 \mathrm{kPa}$ at $0.3 \mathrm{~m}$ depth) are somewhat greater than those measured in the field, and slightly less below $1.0 \mathrm{~m}$. Some of the differences can be attributed to the SWRC used in the calculation, which is not site specific, and is likely to be representative of the intact clay rather than the water retention behaviour of the structured soil including larger voids.

\section{MAGNITUDE AND VARIABILITY OF SEASONAL \\ CYCLES OF PORE WATER PRESSURE CHANGE}

Measurements of soil water content and pore water pressure have been made under a range of seasonal climatic conditions, and a clear link has been demonstrated between the changes in the soil and the climate using a water balance model.

During winter it is clear that the soil profile within the cutting nearly always returns to zero SMD with pore water pressures close to hydrostatic from just beneath the slope surface, even in moderately dry winters (although in the weathered clay at group A, the recovery to hydrostatic conditions was incomplete in the winters of 2004-2005 and 2005-2006, as shown in Fig. 13(a)). This suggests that the magnitude of the summer-winter cycles of pore water 


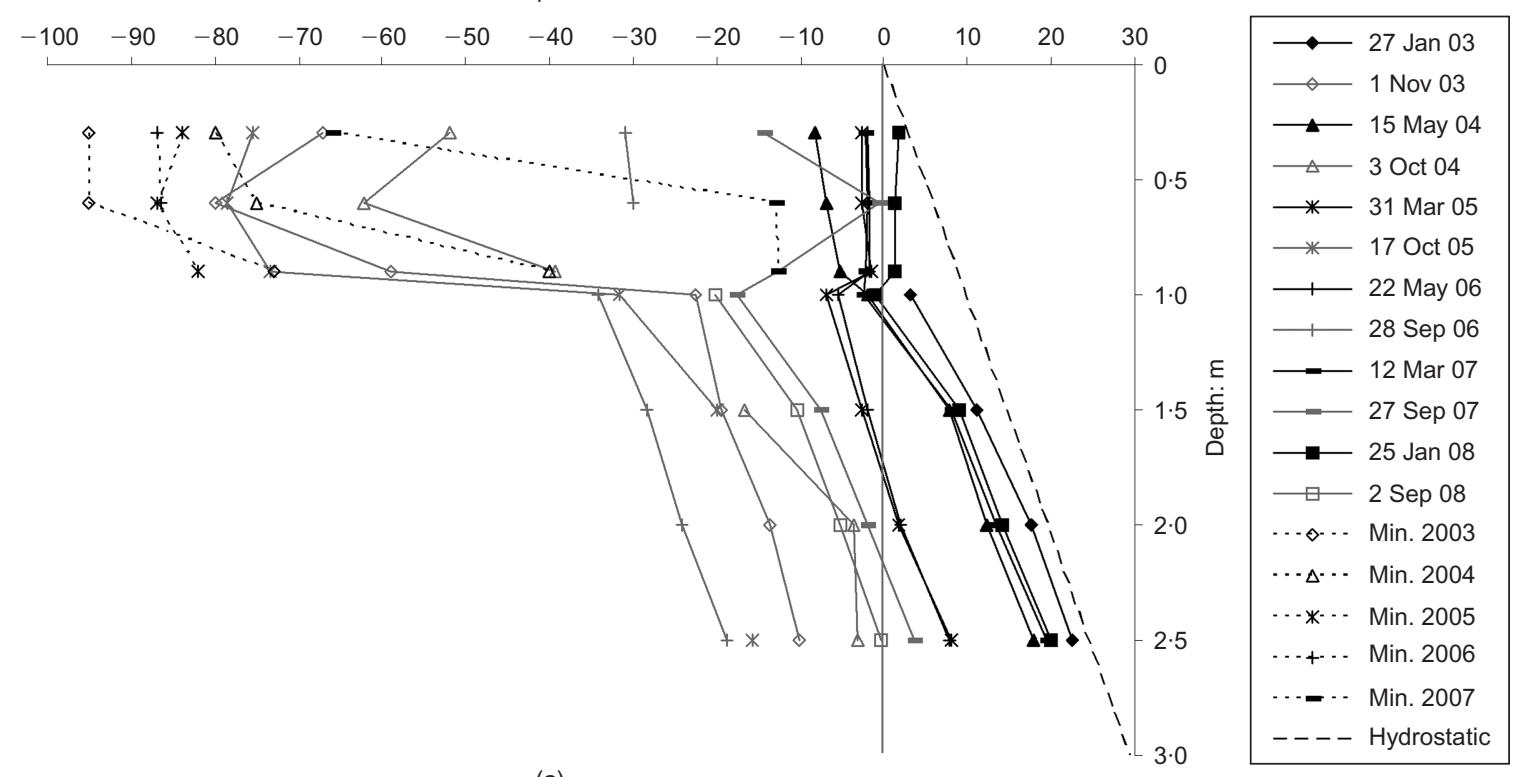

(a)

\section{Pore water pressure: $\mathrm{kPa}$}

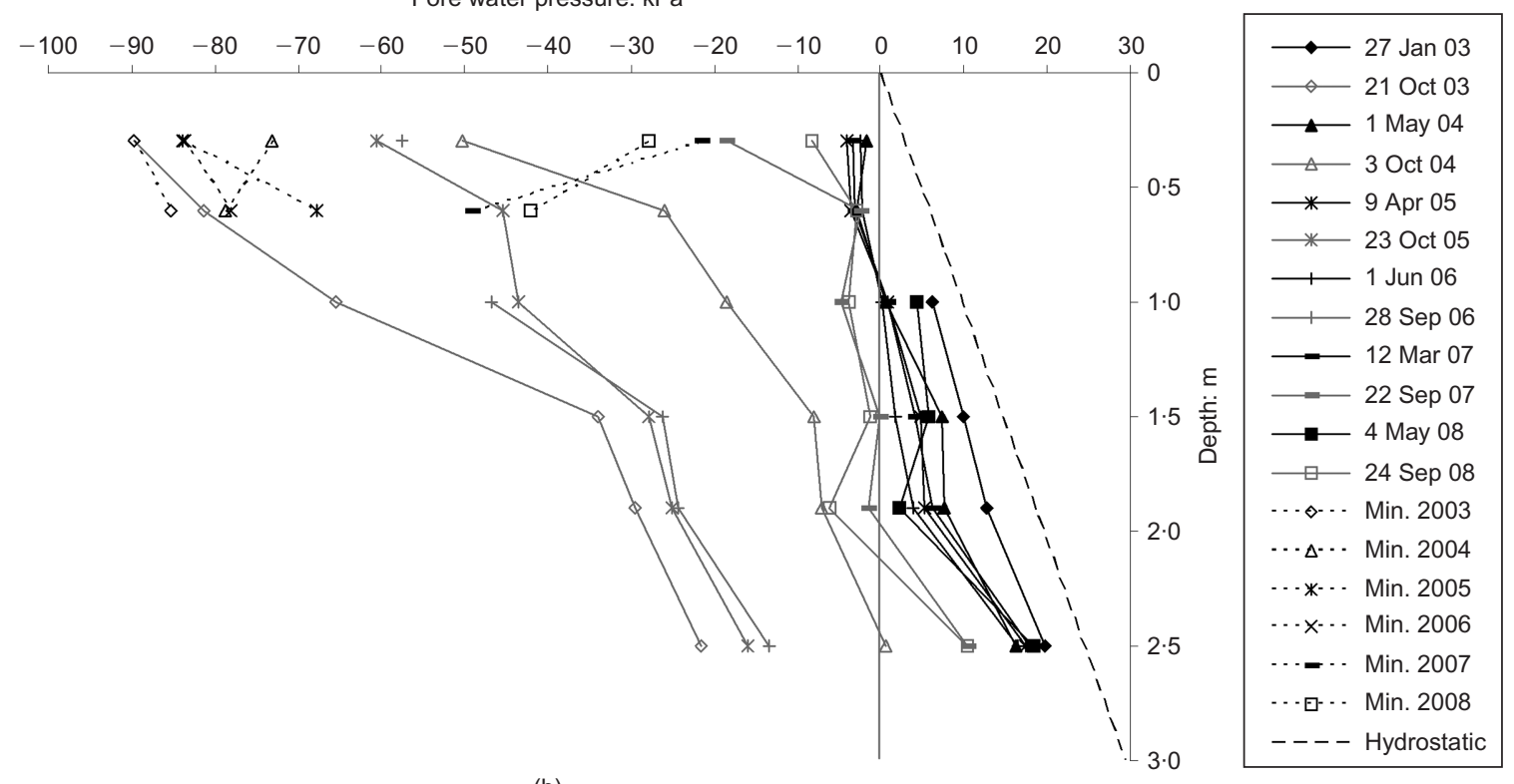

(b)

Fig. 15. Envelopes of annual maximum and minimum measured pore water pressures: (a) instrument group A; (b) instrument group C. The continuous (dated) minimum profiles are plotted at the point where the lower four probes reach minimum pore water pressure: the additional lines (marked 'Min.') show the minimum pore water pressure (maximum suction) measured for the probes at $0.3,0.6$ and $0.9 \mathrm{~m} \mathrm{depth}$ during the summer/autumn period

pressure for a rough grass/herb cover is probably dictated more by the midsummer rainfall than by winter conditions.

Rainfall during the major plant growing season (approximately June to August) is critical to the amount of water extracted from the soil and hence the development of the suction profile. The average June-August rainfall for the 39year Newbury record is $176 \mathrm{~mm}$. The work described in this paper has shown that if the rainfall between June and August is greater than $250 \mathrm{~mm}(\sim 1$ in 5 wet summer $)$, the summer profile will exhibit only small or intermittent suctions. However, if the summer rain is less than $150 \mathrm{~mm}(\sim 1$ in 4 dry summer), substantial summer suctions of $200 \mathrm{kPa}$ or more will be generated in the rooting zone, with suctions extending to depths of around $3.5 \mathrm{~m}$. The threshold of $250 \mathrm{~mm}$ summer rainfall is broadly consistent with an average PET (potential evapotranspiration) of about $2.5 \mathrm{~mm}$ per day (Fig. 6), or a total 3 month PET of $230 \mathrm{~mm}$. A dry summer with only $150 \mathrm{~mm}$ of rainfall establishes a difference with this PET total of $250 \mathrm{~mm}$, and significant soildrying results.

The data and analysis presented in this paper allow the return periods of summer and winter pore water pressure distributions to be developed (Fig. 18, based on the data given in Table 3 and Fig. 7). These are intended to be indicative rather than exact, but are based on measurements from demonstrated periods of fairly extreme rainfall from within a longer rainfall dataset. Continued observations from the Newbury site, and from other sites, could be used to improve the distributions and return periods given. It should, however, be noted that anticipated climate change is likely to change the long-term recurrence intervals; this is discussed by Clarke \& Smethurst (2010). 


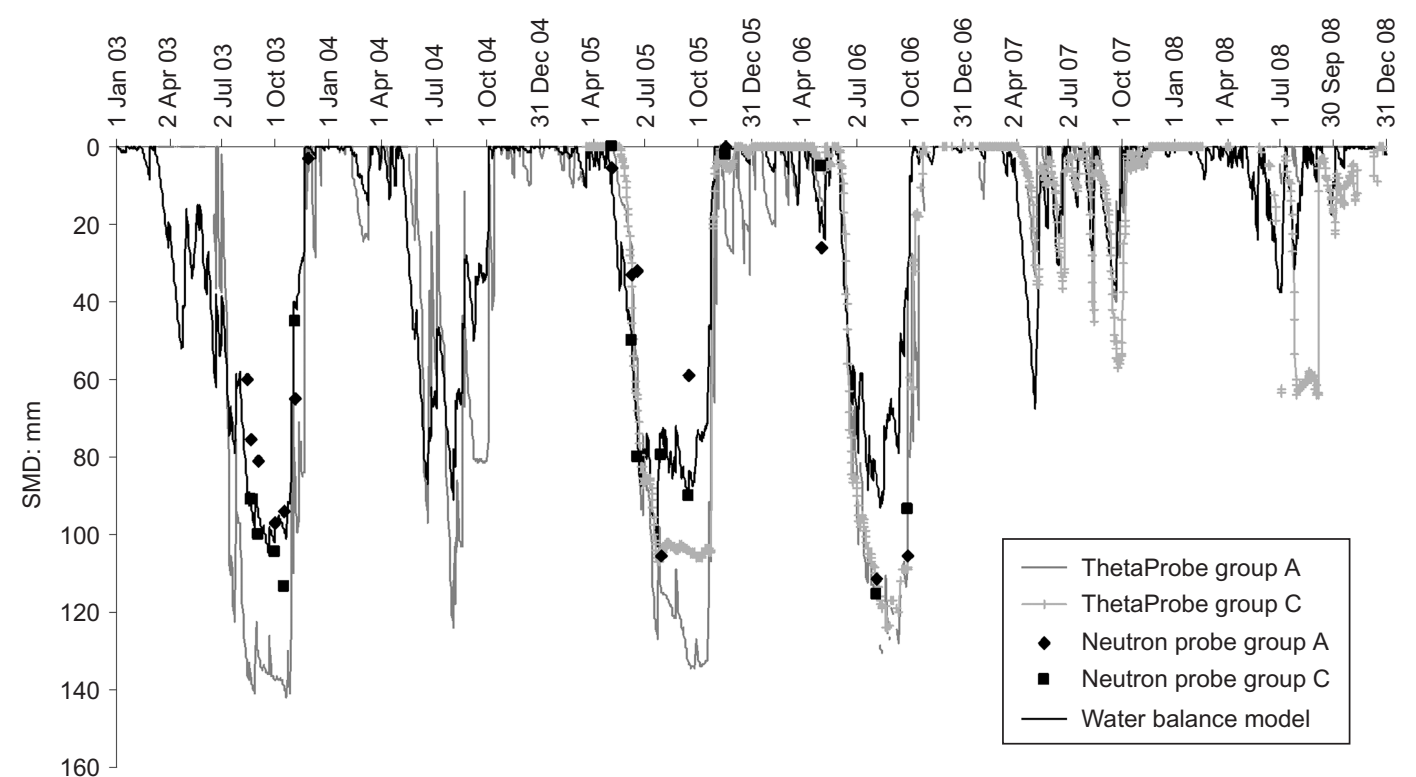

(a)
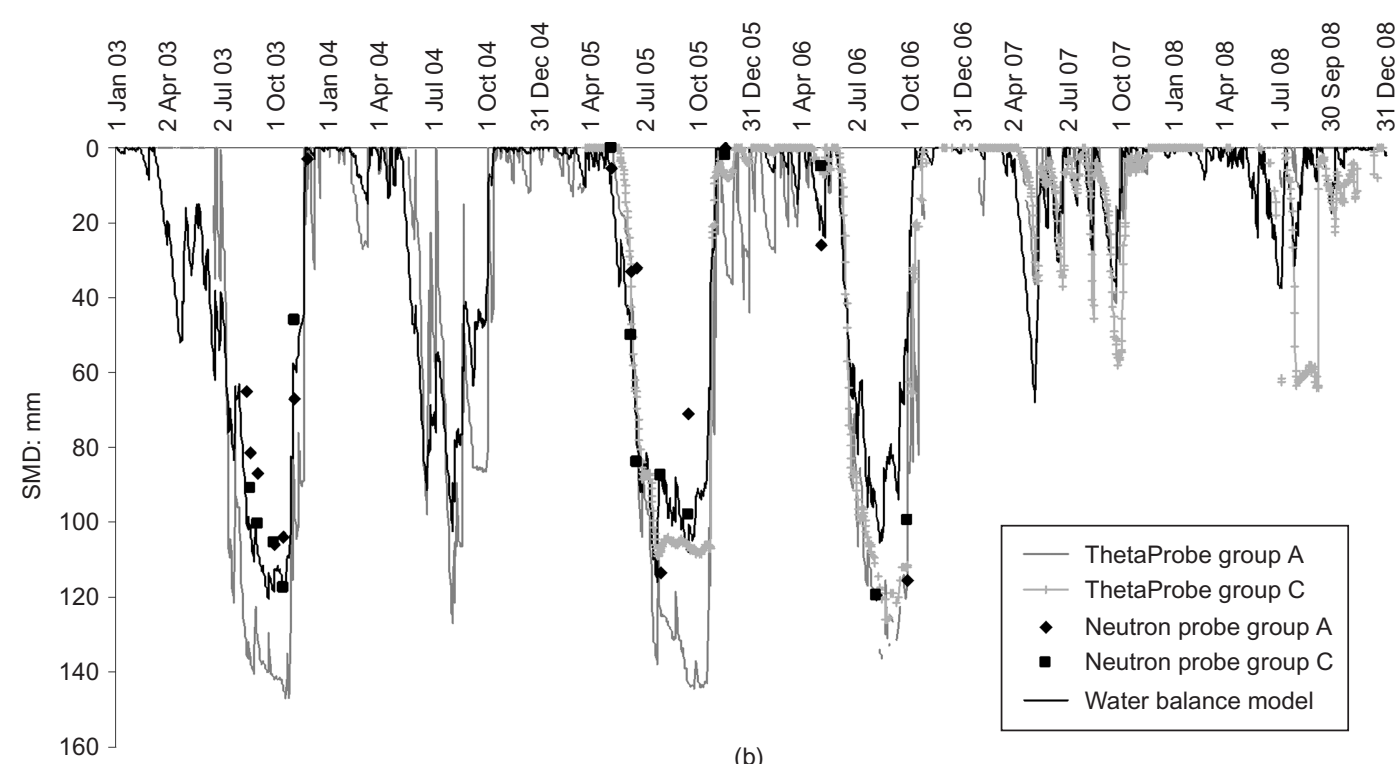

Fig. 16. SMD calculated using the water balance model and plotted with SMD derived from soil water contents obtained using TDR ThetaProbes and the neutron probe, for: (a) soil-rooting zone of $800 \mathrm{~mm}$; (b) soil-rooting zone of $1000 \mathrm{~mm}$

Understanding the climate during the monitoring period, in the context of a longer dataset, provides confidence that near-extremes of seasonal soil water content and pore water have been measured. This is a method that could be used to contextualise shorter sets of monitoring data in relation to wet and dry periods of climate.

\section{INSTRUMENTATION SET-UP AND FURTHER MEASUREMENTS}

The instrumentation set-up used at Newbury was designed to measure near-surface changes in water content and pore water pressures caused by shallow-rooting vegetation, and much of the instrumentation was installed within the top metre of the slope. When the instrumentation was installed it was decided to use multiple approaches to measurement (e.g. TDR ThetaProbe and neutron probe measurements of water contents, which were validated by gravimetric sampling). Experience has shown that reliance on only one type of instrument to measure a key variable may lead to a misleading interpretation. Multiple approaches have provided useful reality checks on what sometimes have appeared to be erroneous readings. The equipment arrays have captured the major changes in the rooting zone well. The seasonal changes in suction, particularly during a dry summer, extend below the deepest probes installed at $2.5 \mathrm{~m}$ depth. Deeper instrumentation is needed to capture the full extent of seasonal change.

The soil permeability plays a major role in infiltration and plant root abstraction processes. It is likely to be quite variable over short depths within the profile, particularly close to the surface, and to change temporally as desiccation cracks open and close. Further field measurements of nearsurface desiccation cracking, and the likely higher permeability caused by the structured nature of the surface soils, would be helpful in supporting some of the suppositions about physical processes that have here been inferred on the basis of measured changes in water content and pore water pressure. 
16

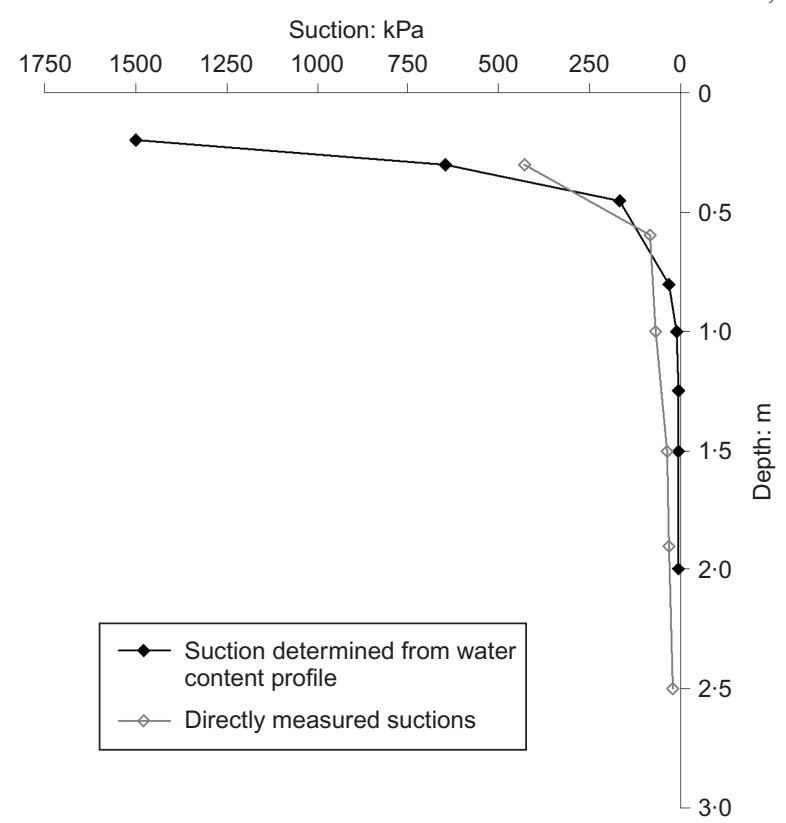

Fig. 17. Suction distribution with depth calculated using Fig. 3 and water content distributions given in Fig. 11(b), plotted with the direct suction measurements given in Fig. 14(b) for the same location (C group, summer 2003)

\section{CONCLUSIONS}

(a) Site-specific climate measurements were made for a cutting slope at Newbury over a six-year period, together with changes in soil water content and pore water pressure. During 2003-2008, the site experienced moderate extremes of wet and dry summers and winters. Annual totals of both potential and actual evapotranspiration were surprisingly consistent over a period that included hot, dry and cool, damp summers. Pore water pressure changes were therefore affected mainly by the variations in actual annual and seasonal rainfall.

(b) Measurements of soil water content show that the vegetation removes water from the root zone, and perhaps $200 \mathrm{~mm}$ below it. In most years there are only small changes in water content below about $1.0 \mathrm{~m}$ depth in the London Clay. The extent and duration of summer suctions correlate well with the measured water content, with large suctions $(>200 \mathrm{kPa})$ forming within the upper part of the rooting zone during average and dry summers, and modest suctions extending to about $3.5 \mathrm{~m}$ below the ground surface during the dry summers of 2003 and 2006 (return period of approximately 3 in 10 years).

(c) Under a rough grass/herb cover, even during dry summers, the vegetation cannot develop a water deficit that will not be almost completely eroded, even during drier winters. Pore water pressures in the cutting return each winter to hydrostatic from close to the ground surface.

(d) The monitoring data have been used to identify several physical processes.

- Drying occurs from the surface first and extends deeper with time, as the plant roots extract water from progressively deeper into the profile.

- Re-wetting in autumn affects the shallow $(<0.5 \mathrm{~m})$ layer first, evidenced by shallow tensiometers losing suction before the deeper piezometers at the end of a dry summer.

- Re-wetting typically occurs fairly rapidly for the Newbury slope, probably as the bulk permeability of the clay has been increased by desiccation cracking and voids left by animals, roots and decayed organic matter.

- Measurements of runoff (surface flow and interflow) show that when there is a moderate soil moisture deficit $(>25 \mathrm{~mm})$ all typical rainfall events are absorbed and little or no runoff occurs.

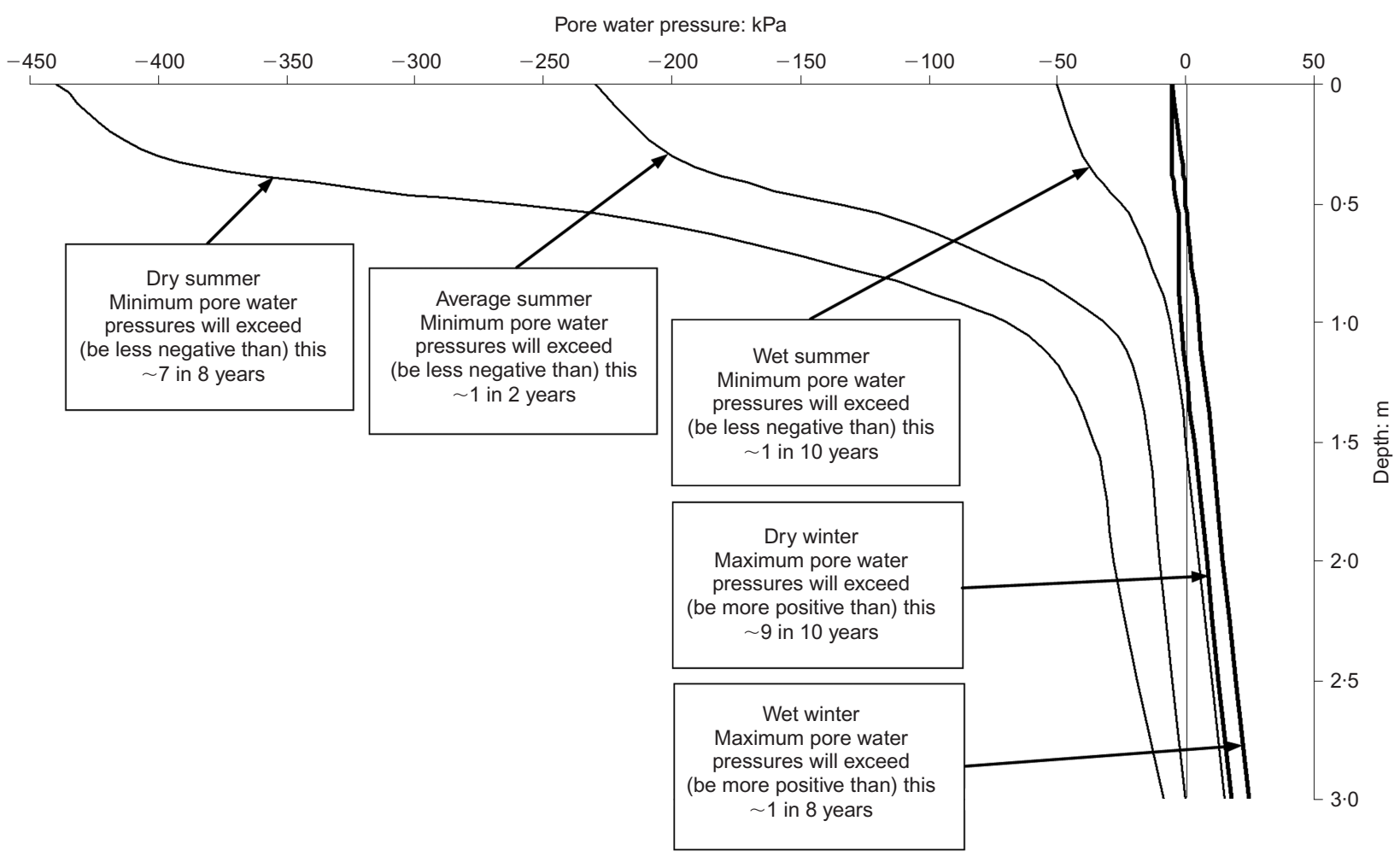

Fig. 18. Approximate distributions of winter maximum and summer minimum pore water pressures and return periods based on field measurements and a 39-year set of rainfall data for Newbury 
Table 6. Water balance model parameters

\begin{tabular}{l|c|c}
\hline & Fig. 16(a) & Fig. 16(b) \\
\hline Vegetation type & Grass/herbs & Grass/herbs \\
Vegetation root depth: mm & 800 & 1000 \\
Available water (as \% of total soil volume) & 18 & 18 \\
Total available water, TAW: mm & 144 & 180 \\
Readily available water, RAW: mm & 58 & 72 \\
Crop coefficient, $K_{\mathrm{c}}$ & $1 \cdot 0$ throughout the year & $1 \cdot 0$ throughout the year \\
\hline
\end{tabular}

(e) A one-dimensional water balance model based on CROPWAT can be used to link climatic data with seasonal changes in soil water content and pore water pressures in the rooting zone, for a rough grass/herb vegetation cover. The model gave a generally good fit to the field-measured data, although there were differences that may result from the limitations of the model, such as its inability to consider lateral flow and exchange of water with the soil below the rooting zone.

$(f)$ Extreme wet or dry summers have a significant effect on the magnitude of seasonal cycles of pore water pressure. Large summer suctions depend heavily on the absence of significant rainfall, particularly in the period June to August.

(g) Profiles of summer and winter pore water pressures have been extracted from the monitoring data and ascribed return periods, based on the 39-year rainfall dataset for Newbury. This method could be used for analysing other sets of monitoring data to understand their context in relation to wet and dry periods of climate.

\section{ACKNOWLEDGEMENTS}

The work described in this paper was funded by the UK Engineering and Physical Sciences Research Council (EPSRC) grant numbers GR/R72341/01 and EP/F063482/1. The rainfall dataset for Newbury was provided by the UK Metrological Office by way of the UK Natural Environment Research Council (NERC) British Atmospheric Data Centre (BADC). The authors are grateful to David Patterson of the UK Highways Agency for permission to instrument and monitor the slope at Newbury. John Perry and Martin Field of Mott MacDonald, and Phil Brown at EnterpriseMouchel, have enabled monitoring activities at the site and provided information on the construction of the A34. Harvey Skinner assembled and has maintained the datalogger systems.

\section{APPENDIX: WATER BALANCE CALCULATION TO EVALUATE ACTUAL EVAPOTRANSPIRATION AND SOIL MOISTURE DEFICIT (SMD)}

The one-dimensional water balance calculation used is

$$
\sum(R-\mathrm{RO})-\sum \mathrm{ET}+S \approx 0
$$

where $R$ is the rainfall, $\mathrm{RO}$ is the run-off, ET is the actual evapotranspiration and $S$ is the change in stored water within the soil.

As the soil dries, the SMD increases until the plants can no longer extract the water that they require, and become stressed. The plant evapotranspiration is then reduced, and actual evapotranspiration falls below the potential value. The model uses the total available water in the active root zone, TAW (typically about $18 \%$ of the total soil volume for a clay soil), but assumes that only a proportion of this can be accessed without causing the plant stress: this is the readily available water, RAW. In a structured clay soil, the RAW will be the water occupying the larger voids, cracks and fissures, while the remainder of the water in the clay peds is harder for the plants to remove. In the calculations here, it is assumed that $\mathrm{RAW}=0.4 \times$
TAW (Smethurst et al., 2006). Both RAW and TAW are expressed as volumes of water per unit area within the zone of drying, and therefore have units of millimetres, the same as the SMD. The parameters for the model used in this paper are given in Table 6 .

While the SMD is less than RAW, evapotranspiration is assumed to occur at the potential rate for the crop (i.e. PET $\times K_{\mathrm{c}}$, where $K_{\mathrm{c}}$ is the crop factor). When the SMD exceeds RAW, evapotranspiration is assumed to fall below the potential rate in proportion to the ratio of non-readily available water (TAW - RAW): that is,

For $0 \leqslant \mathrm{SMD} \leqslant \mathrm{RAW}$

$$
\mathrm{ET}=\mathrm{PET} \times K_{\mathrm{c}}
$$

and for $\mathrm{SMD} \geqslant \mathrm{RAW}$

$$
\mathrm{ET}=\mathrm{PET} \times K_{\mathrm{c}} \times \frac{\mathrm{TAW}-\mathrm{SMD}}{\mathrm{TAW}-\mathrm{RAW}}
$$

Finally, when the soil is at field capacity $(\mathrm{SMD}=0)$, any further rainfall is assumed to run off.

\section{NOTATION \\ ET actual evapotranspiration \\ $h$ discrete height of soil profile \\ $I_{\mathrm{D}}$ plasticity index \\ $K_{\mathrm{c}}$ crop factor \\ PET potential evapotranspiration \\ $R$ rainfall \\ RAW readily available water \\ RO runoff \\ $S$ change in stored soil water \\ SMD soil moisture deficit \\ TAW total available water \\ $w_{\text {vol }}$ volumetric water content \\ $\gamma_{\mathrm{d}}$ soil dry unit weight}

\section{REFERENCES}

Allen, R. K., Smith, M., Perrier, A. \& Pereira, L. S. (1994). An update for the calculation of reference evapotranspiration. ICID Bull. 43, No. 2, 35-92.

Andrei, A. (2000). Embankment stabilisation works between Rayners Lane and South Harrow Underground stations. Ground Engng 33, No. 1, 24-26.

Anderson, M. G. \& Kneale, P. E. (1980). Pore water changes in a road embankment. Highway Engr 25, No. 5, 11-17.

Bell, J. P. (1987). Neutron probe practice, Wallingford: Institute of Hydrology, Report 19, 3rd edn. http://www.ceh.ac.uk/products/ publications/documents/IH19NEUTRONPROBEPRACTICE.pdf (accessed on 1 March 2011).

Briggs, K. M. (2010). Charing embankment: climate change impacts on embankment hydrology. Ground Engng 43, No. 6, $28-31$.

Briggs, K. M. (2011). Impact of climate and vegetation on railway embankment hydrology. Doctor of Engineering thesis, University of Southampton, UK.

Clarke, D. \& Smethurst, J. A. (2010). Effects of climate change on cycles of wetting and drying in engineered clay slopes in England. Q. J. Engng Geol. Hydrogeol. 43, No. 4, 473-486.

Clarke, D., Smith, M. \& El-Askari, K. (1998). New software for crop water requirements and irrigation scheduling. ICID Bull. 47, No 2, 45-58. 
Croney, D. (1977). The design and performance of road pavements. London: Her Majesty's Stationery Office.

Greenwood, D. A. (1998). Speculations on methods of stabilizing slopes. Ground Improvement 2, No. 3, 103-123.

Greenwood, J. R., Vickers, A. W., Morgan, R. P. C., Coppin, N. J. \& Norris, J. E. (2001). Bioengineering: The Longham Wood Cutting field trial, CIRIA Project Report 81. London: Construction Industry Research and Information Association.

Kovacevic, N., Potts, D. M. \& Vaughan, P. R. (2001). Progressive failure in clay embankments due to seasonal climate change. Proc. 15th Int. Conf. Soil Mech. Geotech. Engng, Istanbul 3, 2127-2130.

Loveridge, F. A., Spink, T. W., O’Brien, A. S., Briggs, K. M. \& Butcher, D. (2010). The impact of climate and climate change on UK infrastructure slopes. Q. J. Engng Geol. Hydrogeol. 43, No. 4, 461-472.

Nyambayo, V. P., Potts, D. M. \& Addenbrooke, T. I. (2004). The influence of permeability on the stability of embankments experiencing seasonal cyclic pore water pressure changes. $A d$ vances in geotechnical engineering: Proceedings of the Skempton Conference, Imperial College, London, Vol. 2, pp. 898-910.

O'Brien, A. (2007). Rehabilitation of urban railway embankments: investigation, analysis and stabilisation. Proc. 14th Eur. Conf. Soil Mech. Geotech. Engng, Madrid 1, 125-143.

O'Brien, A., Ellis, E. A. \& Russell, D. (2004). Old railway embankment clay fill: laboratory experiments, numerical modelling and field behaviour. Advances in geotechnical engineering: Proceedings of the Skempton Conference, Imperial College, London, Vol. 2, pp. 911-921.

Parsons, A. W. \& Perry, J. (1985). Slope stability problems in aging highway earthworks. Proceedings of the symposium on failures in earthworks, ICE, London, pp. 63-78.
Perry, J., Field, M., Davidson, W. \& Thompson, D. (2000). The benefits from geotechnics in construction of the A34 Newbury Bypass. Proc. Insth Civ. Engrs Geotech. Engng 143, No. 2, 83-92.

Rouainia, M., Davies, O., O’Brien, A. \& Glendinning, S. (2009). Numerical modelling of climate effects on slope stability. Proc. Instn Civ. Engrs Engng Sustainability 162, No. ES2, 81-89.

Smethurst, J. A. \& Clarke, D. (2007). Climate change impacts on soil drying in clay slopes. Proceedings of the expert symposium on climate change: Modelling, impacts and adaptations (eds S. Y. Liong, K. K. Phoon and D. G. Toll), pp. 165-172. National University of Singapore.

Smethurst, J. A., Clarke, D. \& Powrie, W. (2006). Seasonal changes in pore water pressure in a grass covered cut slope in London Clay. Géotechnique 56, No. 8, 523-537, http://dx.doi.org/ 10.1680/geot.2006.56.8.523.

Take, W. A. \& Bolton, M. D. (2004). Identification of seasonal slope behaviour mechanisms from centrifuge case studies. Advances in geotechnical engineering: Proceedings of the Skempton Conference, Imperial College, London, Vol. 2, pp. 992-1004.

Toll, D. G., Lourenco, S. D. N., Mendes, J., et al. (2011). Soil suction monitoring for landslides and slopes. Q. J. Engng Geol. Hydrogeol. 44, No. 1, 23-33.

Vaughan, P. R., Kovacevic, N. \& Potts, D. (2004). Then and now: some comments on the design and analysis of slopes and embankments. Advances in geotechnical engineering: Proceedings of the Skempton Conference, Imperial College, London, Vol. 1, pp. 241-290.

Weiler, M. \& Naef, F. (2003). An experimental tracer study of the role of macropores in infiltration in grassland soils. Hydrol. Process. 17, No. 2, 477-493. 